\title{
Financing Innovation: A Complex Nexus of Risk \& Reward
}

\author{
Sourish Dutta \\ Centre for Development Studies \\ Trivandrum, Kerala
}

\begin{abstract}
The crucial and growing role performed by different financial intermediaries such as venture capitalists and angel investors as well as more traditional intermediaries such as commercial banks in developing entrepreneurial or innovative firms and boosting product market innovations has led to great research interest in the economics of innovation and entrepreneurial finance. Besides this, there are some important factors or developments which have affected the entrepreneurial finance in general as well as its influence upon different entrepreneurial or innovative firms. Indeed, it is also true that the financial and ownership structures of the different entrepreneurial firms and the legal as well as the institutional environment, in which they operate, itself affects the product market innovations (Chemmanur \& Fulghieri 2014). Therefore, in this paper, I want to target a broad theme i.e. analysis of the mechanisms behind this scenario, especially, in the context of the Indian market system.
\end{abstract}

JEL Classification: O31, O32, G11, G24

Keywords: Innovation, Financing Frictions, Entrepreneurial Finance 


\section{Background: Innovation \& Finance}

Before going to the dynamic relationship between entrepreneurial finance and product market innovations as well as the nexus of risk and reward in this context, it is essential to have some brief ideas about those terms.

\subsection{Innovation}

As the economist and political scientist Joseph Schumpeter famously pointed out, in its essence, innovation is novelty in how value is created and distributed. It could entail new products or services, new methods of production, or indeed novel forms of organising industries and firms (Schumpeter 1934). Therefore, we have to acknowledge that raw creativity alone is insufficient; knowledge of demand and the technology of production as well as execution capacity are also necessary ingredients (Kumar \& Puranam 2012). OECD makes a distinction between product, process-, marketing- and organisational innovations Oslo manual revision 2005. This shows the broadness of the concept of innovation, going far beyond R\&D i.e. beyond the confines of research labs to users, suppliers and consumers everywhere - in government, business and nonprofit organisations, across borders, across sectors, and across institutions. Following this broad definition, two concepts are central to 'innovation' for simplified notion: 'newness' and 'success in the market'. Mr. Innovation himself, the late Steve Jobs, put it more pointedly in Fortune magazine in 1998: "Innovation has nothing to do with how many R\&D dollars you have. When Apple came up with the Mac, IBM was spending at least 100 times more on R\&D. It's not about money. It's about the people you have, how you're led, and how much you get it."(Jaruzelski et al. 2014)

Indeed, innovation is a diversified idea which is to be considered with the introduction of a new feature i.e. it may be new feature to the world or the market or the company. But it must be marked as an improvement in market through an increase in profit. This increase in profit can be the result of a larger market share, the higher price the buyer is willing to pay or lower cost of production and distribution. An innovation can be a better service or product or an improvement in the production process or business model. This innovation can be both incremental, small step, or a more radical or disruptive innovation. What matters is that the innovation contributes to the competitiveness of the firm (van Tilburg 2009). In fact, William J. Baumol argues that innovation plays a role of at least comparable importance for the theory of the firm and competition. Thus, it seems clear that it is innovation, not price-setting, to which management gives priority in important sectors of the economy. It is persistently forced to do so by the market. But the central body of microeconomic analysis gives its attention primarily to price determination, and by doing so may, arguably, be omitting a critical feature of the competitive process in more recent periods. Further, the omission removes the bridge that can connect the static and the dynamic analysis 
(Baumol 2004). Actually, my main aim is to analyse innovation in the Indian real economy or nonfinancial companies due to influences of different financial intermediaries or types of financing and financial innovation.

\subsection{Finance}

Actually, the meaning of "Finance" is: the management of revenues; the conduct or transaction of money matters generally, especially those affecting the public, as in the fields of banking and investment (Dictionary.com 2015). But here we will be more concerned about Entrepreneurial finance, the study of value and resource allocation, applied to new ventures or innovative enterprises. It addresses key questions which challenge all entrepreneurs: how much money can and should be raised; when should it be raised and from whom; what is a reasonable valuation of the start-up; and how should funding contracts and exit decisions be structured (Wikipedia 2015). Basically, if you have a fresh brilliant idea, you probably need fund for its realisation. But how do you realise such a project? It can be answered through entrepreneurial finance which can be analysed most realistically using principal-agent theory due to the special consideration of client/contractor or doctor/patient relation e.g. think about Facebook... from Harvard dorm room to approximately $950 \mathrm{~m}$ users in 2012 . Is it without any financial support? No... It got funding through Peter Thiel, angel investment of 400k in 2004 for approximately $10 \%$ shares and voting power (Source: LA Times).

Innovative enterprises or entrepreneurial firms are, indeed, engines of economic growth and job creation. They seek to commercially exploit new ideas, technologies, inventions or other scientific or market knowledge. There are different development stages in the life of a company before it becomes a commercially successful enterprise seed, start-up, early-growth and expansion. The net cash flow of an innovative enterprise is negative at the seed and start-up stages before it becomes positive. Many of the traditional sources of finance are not fully suitable for innovative enterprises. Given the negative cash flow and high risk of failure at their early stages of development, innovative enterprises ideally need forms of financing that do not seek guaranteed repayment (for Europe 2009). In practice, financing is not free, it requires effort, potential and sometimes painful interventions. Same things happened in Facebook also. Peter Theil's angel investment led to various losses for Zuckerberg and his colleagues, such as dilution of ownership through acquiring $10 \%$ shares, dilution of control with some voting power, taking part in corporate governance as a board member etc. Source: Forbes. I think virtually all capital-formation strategies or, simply put, ways of financing investment revolve around balancing two fundamental/critical factors: risk and reward. These risk and reward factors, generally, exist in both sides i.e. in entrepreneur side and in investor side. Entrepreneur and his source of venture funds will each have his own ideas as to how these factors should be weighted and balanced. Once a meeting of the minds takes place on these key elements, anyone would be able to do the deal. 
- Risk: The venture investors want to mitigate their risk, which an entrepreneur can do with a strong management team, a well-written business plan, and the leadership to execute the plan.

- Reward: Each type of venture investor may want a different reward. An entrepreneur's objective is to preserve his right to a significant share of the growth in his company's value as well as any subsequent proceeds from the sale or public offering of his business.

In general, Basic principles of financing theory, indeed, try to narrow and quantify the development of uncertain situations i.e. information asymmetry, two sided interaction, divergence of interest, time dimension etc.

According to Andrew J. Sherman, a corporate lawyer as well as business \& law school professor, there are twelve different ways of financing any growing business Figure 1. However, some types of financing will be more likely to easily achievable than others based on its stage of growth as well as the current trends within its industry. There are also certain traditional "stepping stones" that are usually followed. As an entrepreneur proceeds along the line of financing, there are fewer choices for financing, and the criteria for qualifying become more difficult to meet, thereby reducing his chances of rising to that level. It is also important to bear in mind that the investors each source of financing on that line may judge the entrepreneur on the quality and success of the deal made on the prior stage. In other words, angels may judge him by the extent of his own commitment, venture capitalists may judge him by the extent of the commitment and reputation of the angels that he attracted, and investment bankers may judge him by the track record of the venture capitalists that committed to his deal (Sherman 2012). Within this list I would try to discuss the details of financing by venture capitalist traditional as well as corporate i.e. IVC and CVC, business angels and crowdfunding in Indian context with some general background.

In this article, I review a recent literature that has addressed the issues and challenges of financial intermediaries or financing of innovation in impacting the product market innovation. As I focus this article on the financing of innovation, therefore I skip many other important factors for innovation: for example, the role of intellectual property, demand-side factors such as the size of the market, the supply of talented scientists and engineers, and spillovers across firms. In addition, we leave out the literature on the impact of technological revolutions on financial markets, which is related to asset pricing rather than the real effects of corporate financing choices (Kerr \& Nanda 2014). But I will try to manage all these topics in future. The schematic arrangement of this article will look like this: Section 2 discusses the usual frictions/barriers behind the financing of innovation, which in turn make it more different type of investment than the investment in other type of project. In Section 3, I do detail analysis theoretical of financing innovation concerning different mechanisms which operate in each channel of capital such as angel investment, venture capital and crowd-funding to some extent between innovators/entrepreneurs and financiers/investors. In this context, I also discuss how far these are the solutions to the financial frictions/barriers to 
innovative activities. Section 4 focuses on financing of different innovative activities in the case of India. Finally, Section 5 critically analyses the implications of this article and outlines some promising areas of Indian financial as well as entrepreneurial system in promoting innovation.

\section{Financing Problems: Some Frictions}

In a frictionless world, where all positive NPV projects are financed, one should not expect the sources of finance to impact the nature of innovation being conducted by a firm. But the real world is full of frictions. There are several features of the innovation process, however, introduce important frictions, and these frictions can lead to financing constraints for firms aiming to undertake innovative strategies, as well as impact how the sources of capital have a bearing on the outcome of the innovation process.Now, if we look at the basic assumptions behind this friction scenario, we would see that there is no perfect market i.e. information distribution is imperfect, leading to positive transaction costs, individuals are self-interest maximiser as well as opportunistic behaviour and so on. In fact, financing of innovative projects or activities is to some extent different from financing other types of projects (Kerr \& Nanda 2014).

- Firstly, It is widely argued that innovative activities are difficult to finance in a competitive market system. It is because of the undesired gap between private rate of return and social rate of return which is termed as spillover gap, leading to under-financing in innovation. In fact, there are many studies or experiments which estimate the rate of return to $R \& D$ financing on the basis of the firm-, industry-, and national-level data. It is clearly resulted that though the examined investments generate high private returns, but the social rates return i.e. the spillover effects between firms, industries or countries, are basically 2-3 times more than that, providing a rationale for public support of R\&D investment. Generally, this argument will be faded in the context of modern intellectual property right system. It is found that following an invention is not costless, it could cost as much as $50-75 \%$ of the original cost of invention. (Hall 2002). In reality, it is important to note that a consideration of how publicly-funded $R \& D$ affects the private sector e.g. developed socioeconomic structure, which is difficult to capture in traditional spillover framework is likely to underestimate the social returns to this financing (Frontier Economics Ltd 2014).

Nevertheless, $R \& D$ is not the only activity driving innovation. Other activities such as design, software and firm-specific human capital represent significant amounts of financing by firms, and much less is known about the private and social returns to these wider financing (Frontier Economics Ltd 2014).

- Secondly, using a systematic approach to reviewing the literature, eight factors which create uncertainty in processes of innovation are identified, namely: technological uncertainty, 


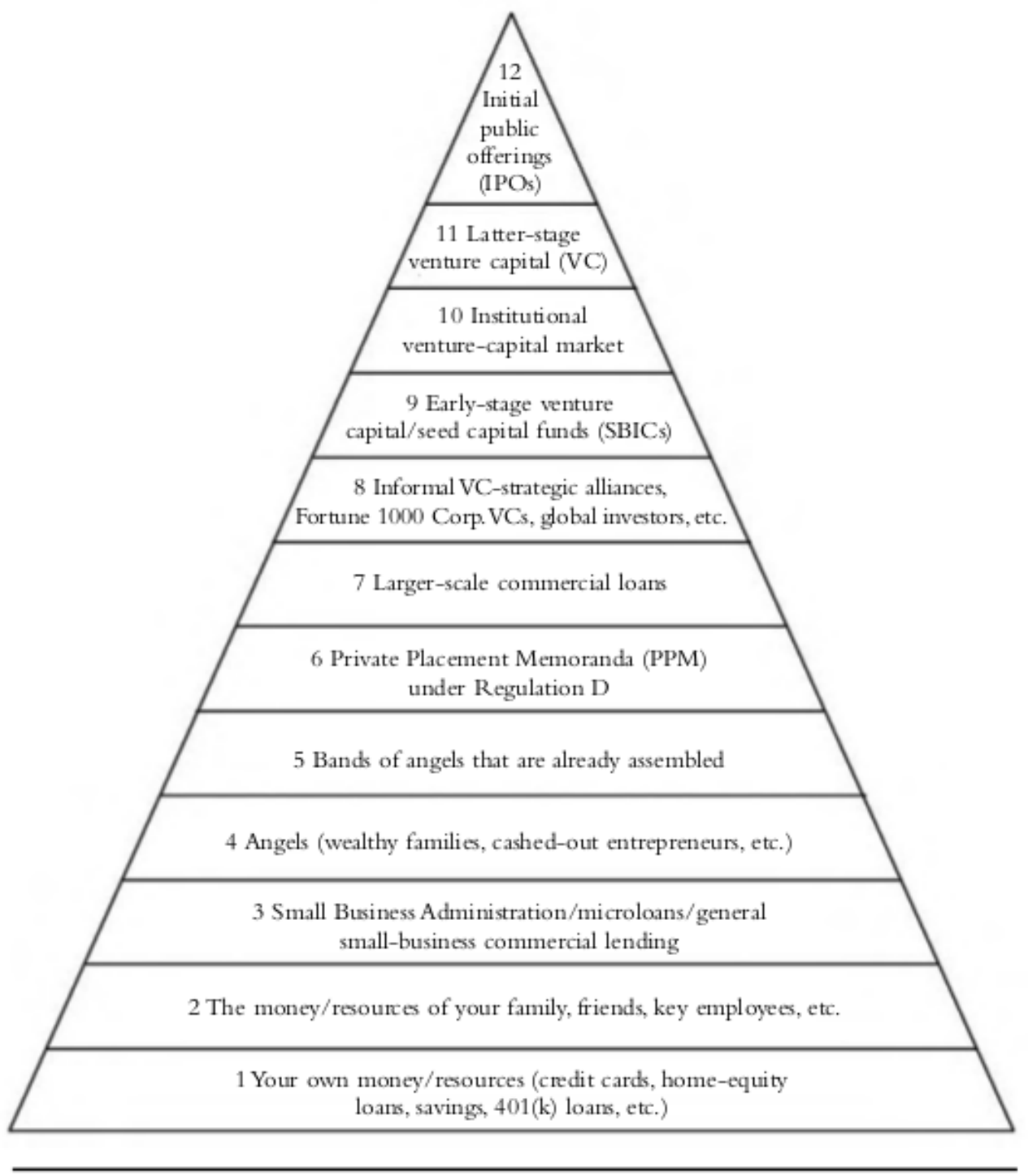

Figure 1: Twelve different ways of financing any growing business 
market uncertainty, regulatory or institutional uncertainty, social or political uncertainty, acceptance or legitimacy uncertainty, managerial uncertainty, timing uncertainty, and consequence uncertainty (Jalonen 2012). Indeed, investors must typically decide whether or not to fund an innovative project with very limited knowledge of the odds of success, a situation that is best described as "Knightian uncertainty", which cannot be calculated via probabilities, whether objective or subjective Knight, 1921; (Dicks \& Fulghieri 2014); (Mazzucato 2013). The factors of overall uncertainty and their manifestations in innovation processes are in the following:

\section{- Technological Uncertainty:}

* Due to the novelty of technology, as its details are unknown

* Uncertainty regarding knowledge required to use new technology

- Market Uncertainty:

* Unclear customer needs

* Lack of knowledge about the behavior of competitors

* Difficulties in predicting the price development of raw materials and competing products and services

- Regulatory or Institutional Uncertainty:

* Ambiguous regulatory and institutional environment

- Social or Political Uncertainty:

* Diversity of interests among stakeholders of innovation processes

* Power struggle

- Acceptance or Legitimacy Uncertainty:

* Necessary skills and knowledge contradict existing skills and knowledge possessed by perceived users of innovation

* Innovation threatens individual's basic values and/or organization's norms

- Managerial Uncertainty:

* Fear of failure

* Lack of requisite tools to manage risk inherent in innovation process

- Timing Uncertainty:

* Lack of information in the early phases of innovation

* Ambiguity of information in the late phases of innovation

* Temporal complexity

- Consequence Uncertainty:

* Indirect consequences

* Undesirable consequences 


\section{* Unintended consequences}

- Thirdly, in financing innovative activities, although we know that two sided cooperation is required, but sometimes it is true that an entrepreneur plays most important roles to make successful his/her company like Mark Zuckerberg for Facebook, Jeff Bezos for Amazon. Now question is: what are common success factors? I think due to exploratory spirit, discipline and good business sense some entrepreneurs become more popular. In addition to this, as a potential one, a successful entrepreneur could predict the success of new idea in the future i.e. he could estimate or project the global market potential and sales figure of some product/service, he could foresee the technological challenges and potential behavioral changes of that produced product/service. Actually, an entrepreneur as well as investor may be try to mitigate those above mentioned uncertainties or factors of partial transparency. However, the financing process in innovative startups can be described as a multi-stage principal-agent problem Figure 2 where the simple problem is marked by red dashes exchanging investment and return between principal and agent. So what does one do in this problem? It actually depends on the what stage of financial relationship one looks at i.e. before they did the deal which is the left side in that figure Figure 3 or after the deal. In left side, we have double sided problem i.e. the hidden characteristics are from entrepreneur as well as investor side, and if they don't look at the potential relationship in a good way, they would end in adverse selection. So it might be the case that in one hand the financier is financing in such company that is not making money, and on the other hand innovator obtains financing from someone who is not helping at all. After the deal has taken place, there is single sided asymmetry i.e. the financier here it is VC has to prevent the hidden characteristics from innovator side e.g. whether he/she is working well or not. This last problem generates, generally, a moral hazard and in order to reduce this the financier has to do excessive screening as well as to match their interests at the same line. Is it practical? Answer is yes of course... for instance, we can refer the case of Motionloft, an analytics company, whose $\mathrm{CEO}$ was accused of defrauding financiers. Therefore, some financiers are not as savvy as Peter Thiel and spend money lavishly (Brettel 2014).

- Fourthly, according to David Dicks and Paolo Fulghieri in a preliminary and incomplete article on Uncertainty and Innovation, uncertainty aversion generates innovation waves. Uncertainty aversion causes investors to treat different uncertain lotteries as complements, a property that we refer to as uncertainty hedging. Uncertainty hedging by investors produces strategic complementarity in entrepreneurial behavior, producing innovation waves. Specifically, when one entrepreneur has a successful first-stage project, equity valuation, entrepreneur utility, and the intensity of innovation increase for other entrepreneurs as well. Thus, entrepreneurs are more willing to innovate if they expect other entrepreneurs are going to innovate as well, resulting in multiple equilibriums. Therefore, their model can thus explain why there are some periods when investment in innovation is "hot,"and venture capitalists are more willing to invest in risky investment projects tainted by significant 


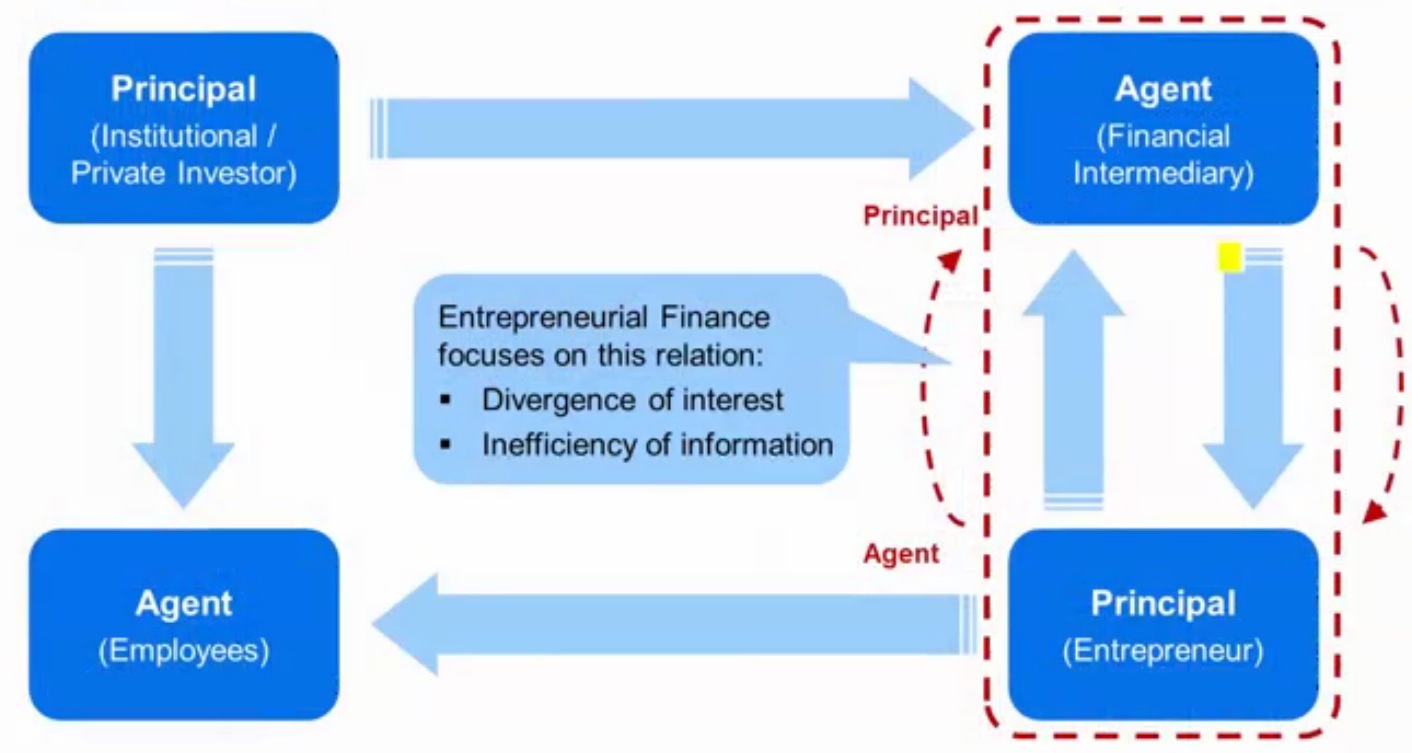

Figure 2: Multi-Stage Principal-Agent Construct

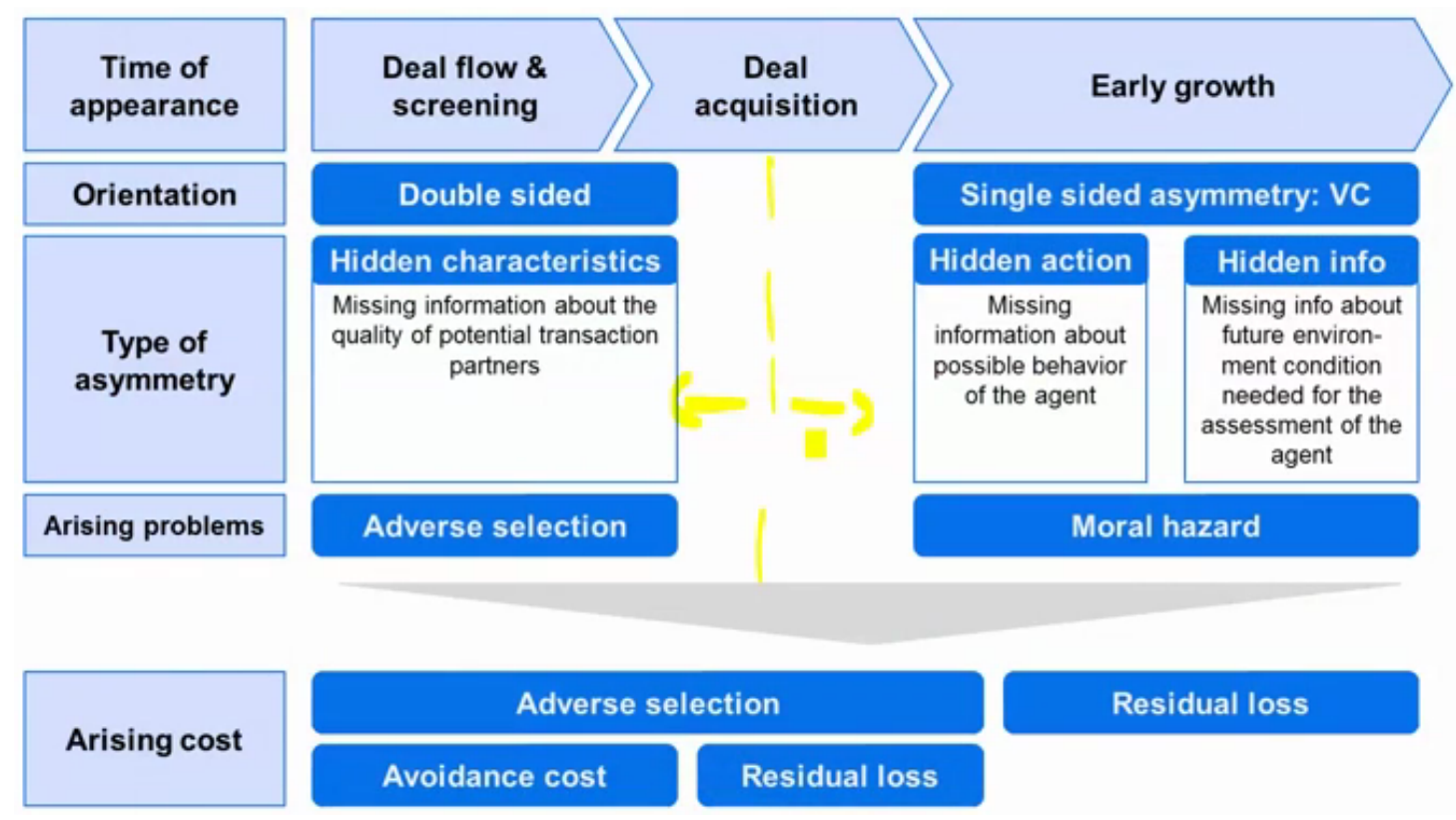

Figure 3: Information Asymmetry 
uncertainty (Dicks \& Fulghieri 2014).

Therefore, we can see that although the uncertainty and its various forms create some frictions or barriers in financing innovation, it ultimately leads to more and more innovations through innovation waves.

\section{Financing Innovation: Theoretical Discussion}

Actually, in this article I am more concerned about the financing of different start-ups rather than the financing of established publicly listed companies. Now the question is: what is the difference between a established publicly listed company and a start-up? However, this difference would ultimately lead to the difference between corporate finance and entrepreneurial finance. Think about two companies... One is Daimler and another is Outfittery. First of all look at Daimler and you like to buy some shares of it equity investment/public equity. In fact, you know that what Daimler is doing? It builds cars and you may have seen the models, you can look into broker report or other reports etc. And after analysis, although you would face some risk as it is an equity investment, you could be pretty sure about the financial health of the company. But it is also true that the massive fluctuations are less probabilistic. That's all. Now look at another example i.e. Outfittery, a style consultancy firm. In this case, we have to think that is it a good idea to start a business? They started well. Suppose you put equity investment in this company. Are you sure that you can get something back. Indeed, it will depend on many factors viz. goodness of that idea, entrepreneurial and other skills of the founders. On the basis of those considerations, you might invest some money in this company. But here the major factor is uncertainty not the risk. Because the probability distribution is unknown to you. And this is the entrepreneurial finance, which is about the financing of start-ups. Actually, these companies are very uncertain about their future and their success or failure truly depends upon the activities of the committee members. Basically, uncertainty is a part and parcel of innovative activity.

However, in the figure Figure 4 the pre-early stage financing is the product of uncertainty. In fact, you can cope with this uncertainty only through the equity investment in diversified portfolio, where returns from the successful start-ups could compensate the losses due to some failed startups. In addition, the funding is not only means in this cycle, but also the managerial supports of the angels and VCs i.e. capital with some support elements is the engine for this type of financing. So possibilities above and beyond the financial investment should be taken into account.

There are various financing sources Figure 5, but I will focus only on equity financing, especially external equity financing. And at the end of the day if we ask ourselves who will give the money?, then we can find, more all less, five possible sources Figure 6 i.e. Family \& Friends, crowd-funding, 


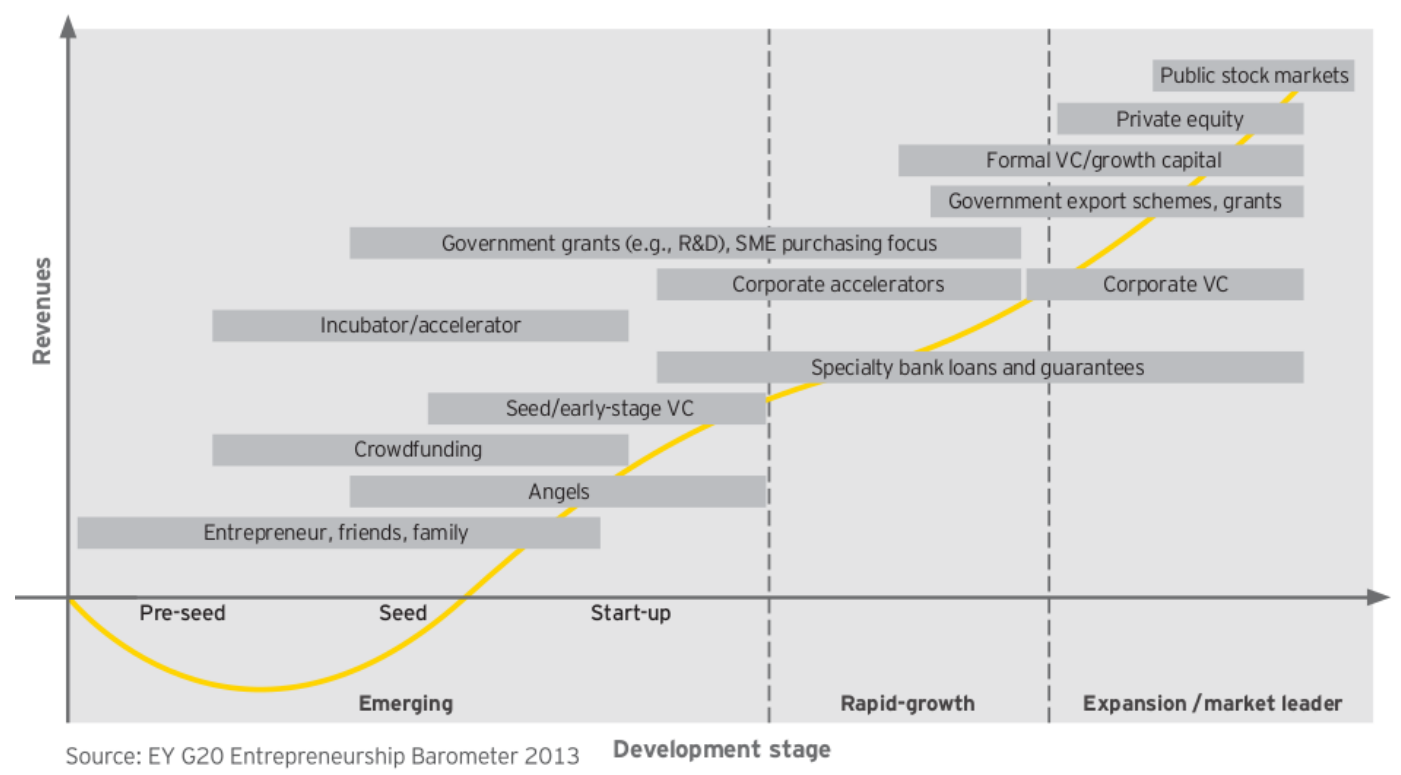

Figure 4: Startup Financing Cycle

business angels, venture capitalists IVCs, and strategic investors CVCs. All these sources are external equity financing. Moreover, early phase equity financing is differentiated into a informal and formal part. family \& friends as well as business angels are in informal equity, whereas strategic investors as well as venture capitalists are in formal equity.

Now, in the next subsection, we will discuss some underlying mechanisms in these financing which in turn lead to the solution of the financial barriers/frictions in any innovative start-up. However, as there is a less possibility of getting added value in the form of know-how or expert advice in the case of financing through family \& friends or crowd-funding, we will neglect those in this article. Thus, the whole discussion would revolve around the financing through angels and venture capitalists.

\subsection{Financing Through Business Angels}

Angel investing is something highly successful... For example, Google, Facebook, Amazon, Twitter etc. all innovative companies were financed through angel investments at the beginning. So obvious question is: what is the definition of a business angel? Basically, business angel is a wealthy individual who invests in different start-up companies with his/her own money and expertise. As an example, Rajan Anandan, the Google India MD, is one of the most experienced individual angel investors in India. He has backed more than 40 Indian start-ups. This type of 


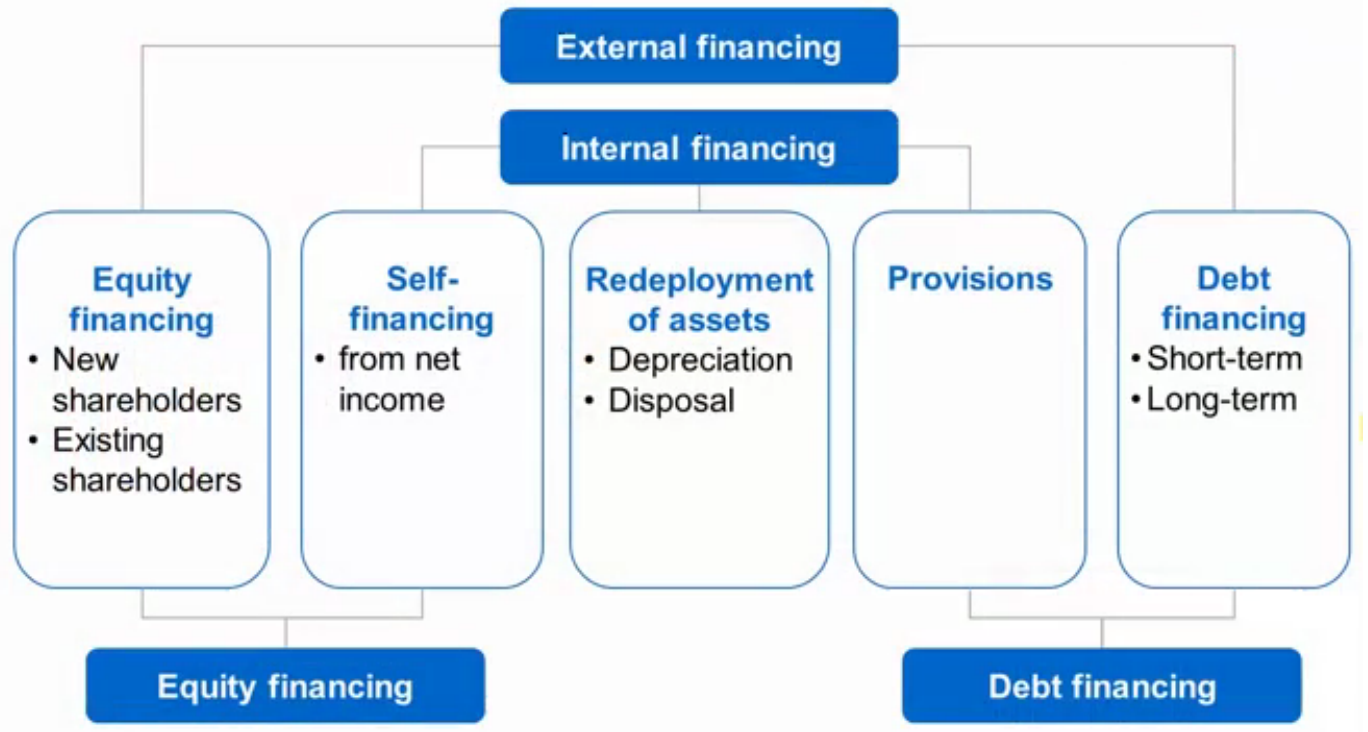

Figure 5: Sources of Financing

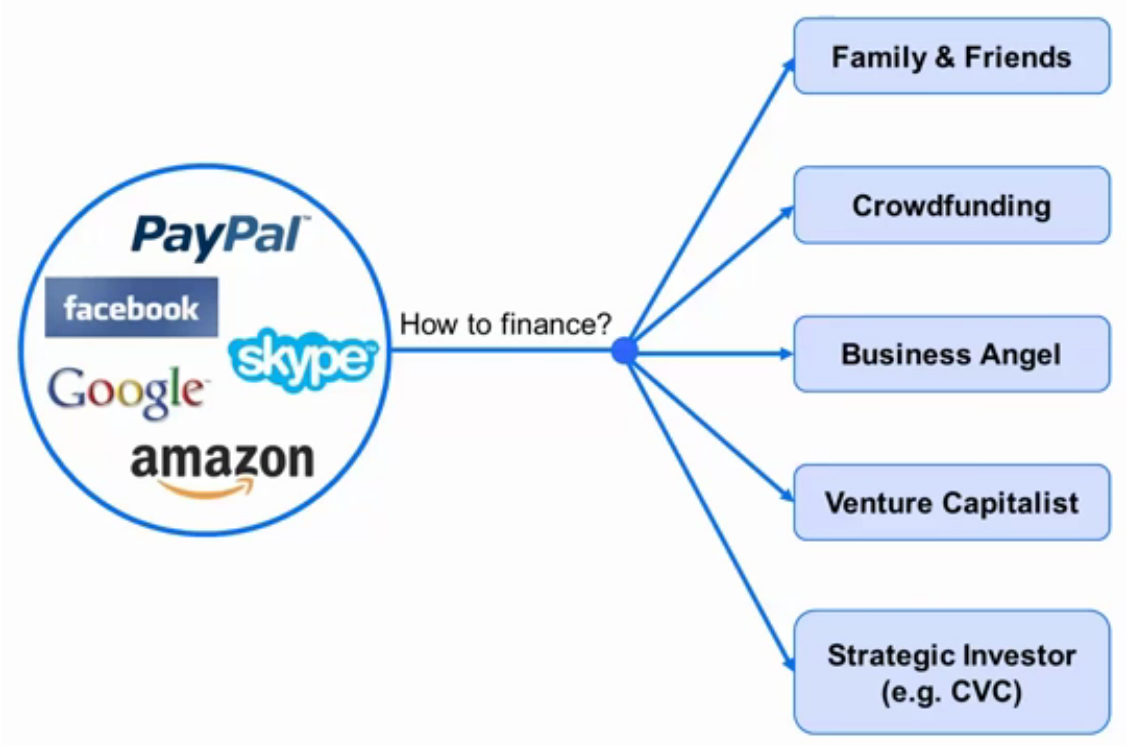

Figure 6: Who gives you the money? 


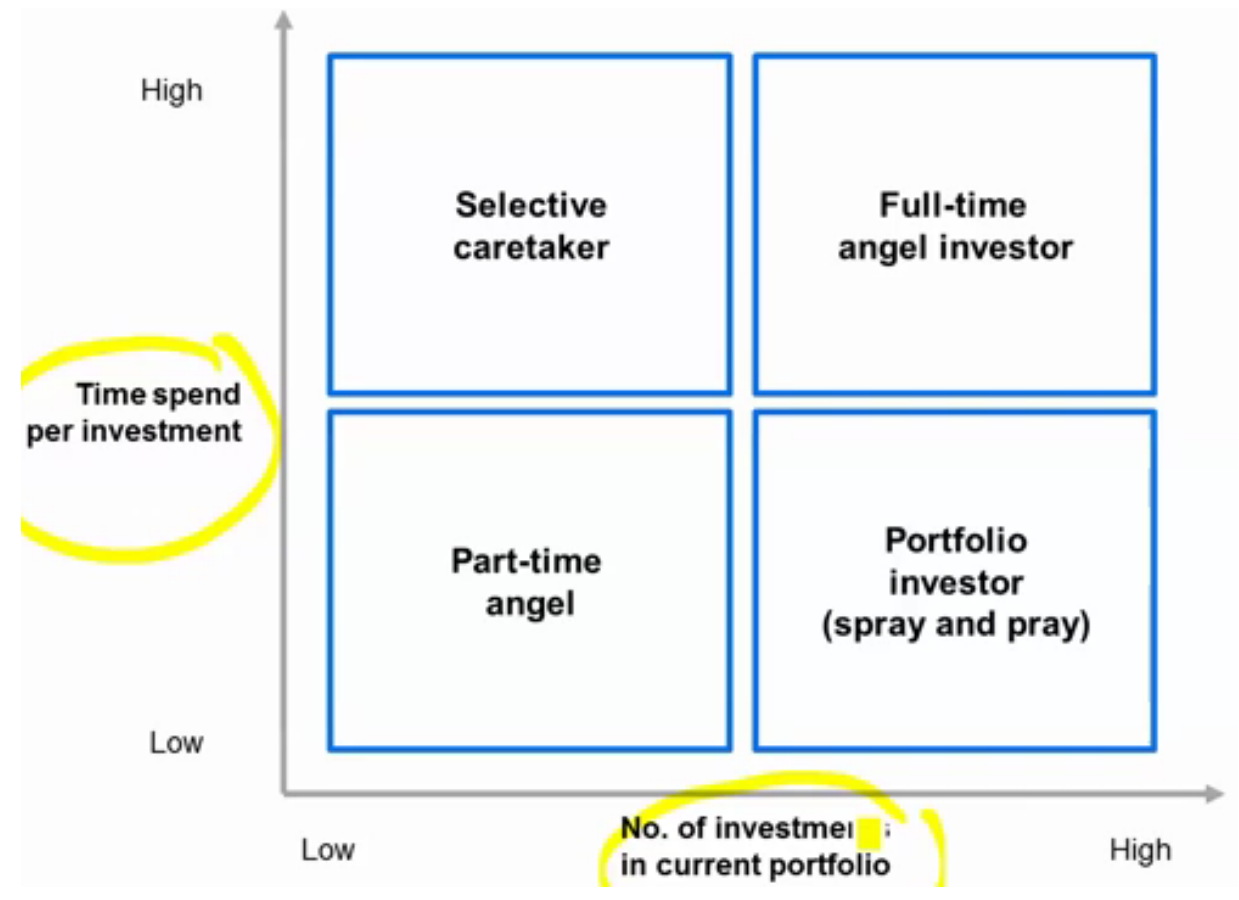

Figure 7: Different Types of Business Angels

individuals provides equity or quasi-equity funding to growth-oriented companies with the aim of achieving a financial return through capital gain at exit. In addition to money, business angels also provide value-added services. In fact, business angels are private investors, but not all private investors are business angels. The private investors who are purely interested in return, but not in additional supports, are not considered as business angels.

There are four different types of business angels according to time spent per investment and number of investments in current portfolio (Brettel 2014). Those are:

1. Selective Caretakers: They spend a lot of time and only picking the cherries. Actually, they are serial entrepreneurs or highly experienced former managers. Their expectations about failure are very low no real portfolio strategy.

- Example: Catarina Fake co-founded Flicker along with Stewart Butterfield. She has few and selective investments in Esty and Kickstarter.

2. Part-time Angels: They generally have full-time job but have enough money to invest. Basically, they are new and inexperienced investors or non-lead "expert investors". They often still with full-time investment. They are very young but they also have mixed investment portfolio. 
- Example: Ashton Kutcher actor, producer and former model. He has several high profile investments such as flipboard, Airbnb, Skype etc.

3. Portfolio Investors: They have a lot of diverse investments but they also hold chairman or CEO positions. They, generally, encounter good financial windfall as well as act as internet investors with non-lead participants. They have very young investment portfolio.

- Example: Ron Conway the super angel founder and managing partner at Angel Investors. He has a lot of small investments with outstanding performance e.g. Google, Facebook, Twitter,Paypal etc.

4. Full-time Angel Investors: They have a diverse portfolio and spend most of their time investing in promising start-ups. They have long experience as angel or vc investor with back office and fund structure.

- Example: Reid Hoffman VP of paypal, founder of Linkedin, partner at Greylock. Forbes called him "Silicon Vally's uber-investor."

Now we have to see that how do business angels do business? This can be expressed in a three stage process Figure 8. However, at the end of the day, business angels are mainly motivated by fun and interest in their potential target and its team (Brettel 2014). In reality, presence of different angel networks have made the financing process much easier and organised. But the pitching, screening, monitoring and due diligence things become more and more rigorous than before, helping accurate and efficient fund management. Angels can also consider making multiple rounds of financing based on the progress achieved in the earlier round of financing. Besides this, angel investment also shares a clear difference in approach from acceleration and incubation. Though they offer entrepreneurs/innovator good opportunities early on, they basically differ with each other for the degree of financial support as well as management/expertise support and network effect (Rajan \& Jain 2012).

\subsection{Financing Through Venture Capital}

The definition of venture capital is clear and grounded in theory. In general, venture capital is characterised by the following:

- Venture capital firms supply equity capital or corresponding capital for high growth, young, small and medium companies.

- Venture capital financing consists not only in supplying financial resources - it is linked tightly to the offer of management services for the companies receiving the investment. 

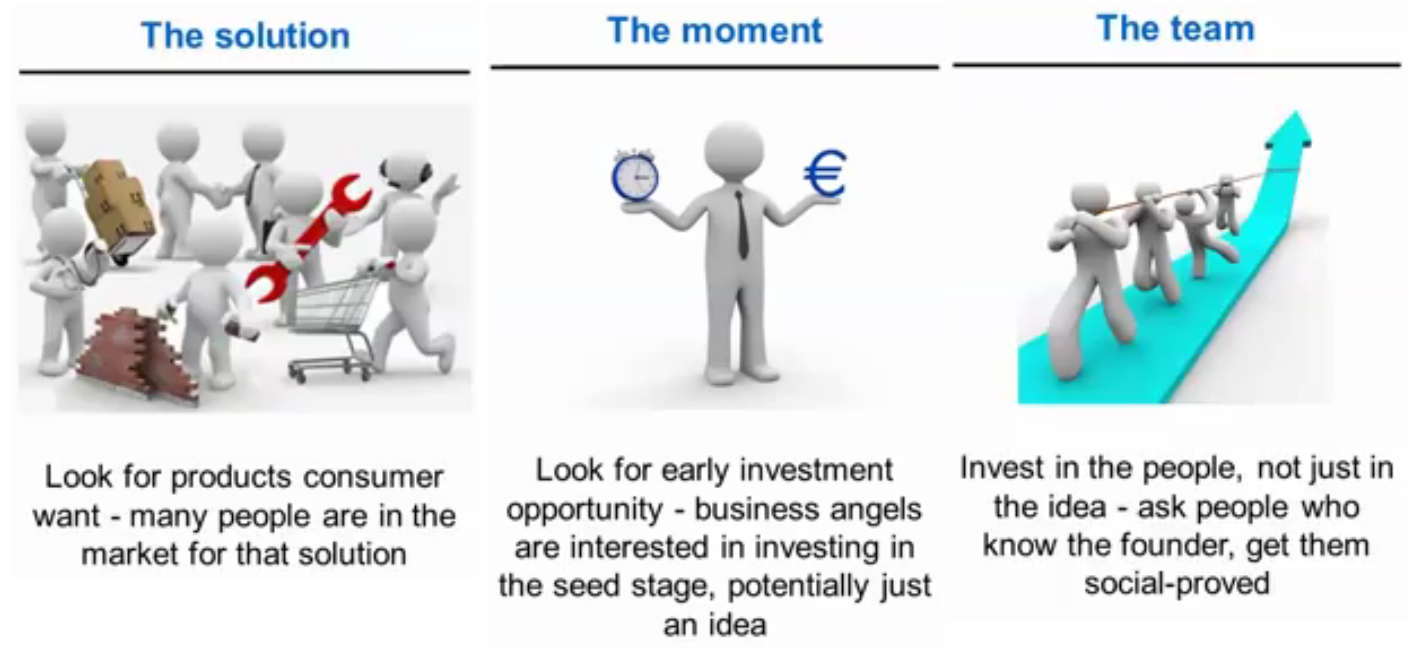

Invest in the people, not just in the idea - ask people who know the founder, get them social-proved

Figure 8: Business Fundamentals of Angels

- Venture capital companies are investors with a long-term perspective which achieve their return through capital gains.

Indeed, though both angel investment and venture capital are apparently same, there are some differences on the basis of degree of financing and management support Figure 9. Besides this, in case of venture capital, you will get a heterogeneous network of investment as venture capitalists manage the pooled money of others. Nevertheless, venture capital companies can be categorised in to various groups. Those are:

1. Pure Investment Companies: They are most common venture capital form. They invest into small and medium-sized companies in all phases which are not traded on stock exchage.

- Example: Sequoia Capital, Greylock Partners etc.

2. Corporate Investment Companies: They are typical venture capital fund within a big and established companies. They invest mostly in hi-tech start-ups within familiar sectors or in completely new business idea.

- Example: Bosch,Intel capital, Google Ventures etc.

3. Publicly Funded companies: They make available capital from public sources. These venture capital companies often provide subsidised loans at reduced interest rate in the form of dormant stakes in companies.

- Example: High-Tech Gründerfonds etc. 


\begin{tabular}{|c|c|c|c|c|}
\hline \multirow[b]{2}{*}{ Financing } & \multicolumn{2}{|r|}{ Business angel } & \multicolumn{2}{|r|}{ Venture capitalist } \\
\hline & & & & \\
\hline Phases & $\cdot$ & Start-up phase & - & Start-up and expansion phase \\
\hline Volume & $\cdot$ & Up to EUR $0.5 \mathrm{mn}$ & $\cdot$ & More than EUR $0.5 \mathrm{mn}$ \\
\hline Regional limitation & $\cdot$ & Reduced action radius & $\cdot$ & No limits \\
\hline Motive & 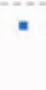 & $\begin{array}{l}\text { Monetary and non-monetary } \\
\text { motives }\end{array}$ & - & Solely monetary motives \\
\hline \multicolumn{5}{|c|}{ Management support } \\
\hline Control rights & - & Less important & 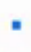 & Very important \\
\hline Information rights & $\cdot$ & Less formalization & 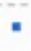 & Very formalized \\
\hline Influence & 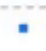 & Irregular feedback & " & Regular \\
\hline Personnel resources & 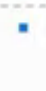 & $\begin{array}{l}\text { Only the angel's own capacity is } \\
\text { available }\end{array}$ & 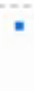 & $\begin{array}{l}\text { Systematic help in identifying } \\
\text { and resolving deficits }\end{array}$ \\
\hline
\end{tabular}

Source: Engeimann (2000)

Figure 9: Angels vs VCs

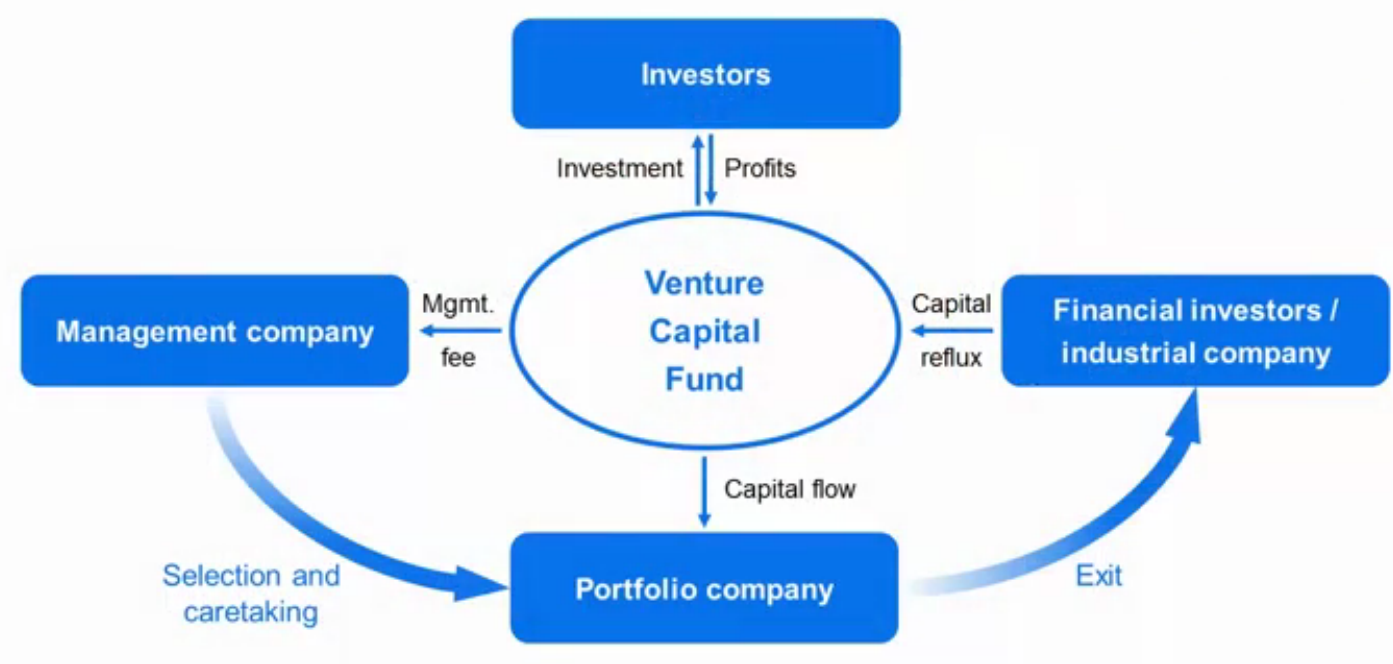

Source: Geigenberger (2000)

Figure 10: Structure of Investment Through Venture Capital 
In real situation, financing through venture capital takes a cyclical form, starting from upward trend i.e. increasing returns \& increasing capital inflow to downward trend i.e. oversupply \& falling returns - little capital inflow in the financial market. Although after recovery of the market it follows the same cyclical process, but the time interval of each complete cycle is uncertain to us.

In this context we can also discuss the corporate venture capital CVC. The fundamental idea behind the CVC is how to make the large corporations become more entrepreneurial? Now it is a complete package of motivating, organising, financing and managing different innovative start-ups. Moreover, the goals of CVC are much more diversified than that of real or independent venture capital IVC. In reality, besides the financial goals of high returns and the social/PR goals for image benefits, $\mathrm{CVC}$ has additional four strategic goals i.e. collecting technological knowledge, promoting entrepreneurial spirit, increasing efficiency, and enhancement of growth possibilities. Therefore, it is the duty of an innovator/entrepreneur to think of a strategy or set of strategies through selecting financial intermediaries which would be fit for his start-up (Brettel 2014).

\subsection{Angel Investment and Venture Capital: Some Studies}

On the basis of above fundamentals of angel and venture capital investment, it can be easily argued that angels and venture capitalists foster innovative activities within an economy not only through the provision of financing, but also through a complete package of acute monitoring and screening, developing efficient management teams, and enhancing network in related sphere. In fact, these ingredients/inputs try to offset those above mentioned frictions or financial barriers regarding the financing of innovation. However, due to lack of data in early stage ventures, there are very little studies examining the above claims in the case of angel investment e.g. (Kerr et al. 2014), though there are some practical studies supporting the above assertion about venture capital e.g. (Hellman \& Puri 2000); (Chemmanur et al. 2011).

One major problem of examining the effectiveness of different financial intermediaries such as angels or venture capitalists in boosting different innovative activities is the endogeneity of the intermediaries' decision to finance i.e. financiers are, generally, interested to finance some innovative and fresh ideas creating enormous value in future or some excellent things of the start-ups might influence financier as well as the expansion path of those firms. So causal analysis between the intervention and performance is to some extent difficult for start-ups (Chemmanur \& Fulghieri 2014). But this problem is managed in (Kerr et al. 2014) paper by using regression discontinuity approach. In this paper, they find a significant upward jump in the performance, likelihood of sustaining in future, successful exits, and employment level of the financed start-ups by two angel groups. Overall, it is found that the successes of different start-ups are dependent upon the special value added services of those financial intermediaries. 
Similarly, in (Chemmanur et al. 2011) paper examines several related questions regarding the efficiency gains i.e. TFP, pre and post investment analysis, sales or reduction in costs, and different ways of successful exit etc. generated by venture capital VC investment in private firms. Their analysis depicts that the overall efficiency of VC-backed firms is higher than that of non-VCbacked firms at every point in time, and it is mainly due to the additional strict services provided by those VC firms. Nevertheless, if analyse about comparative effectiveness of nurturing product market innovation through angels an venture capitalists e.g. (Goldfarb et al. 2009), we would get that as angel investors being cash constrained, VC participation is a necessary condition for financing larger innovative activities. From that paper, we can also find that VCs obtain more rigid control rights in early stage financing relative to angel investors, consistent with $\mathrm{VC}$ participation in managing the firms they invest in.

Besides this, there are several studies which have showed that the role of the financing through private equity is also very much effective for spurring innovation within an economy. (Lerner et al. 2011) paper examines the effect of investments by private equity groups on firms' longrun investments, focusing on innovative activities as measured by patenting activity. They have found that the post-PE financing for some sample US firms leads to more frequent citation of their patents. Similarly, there is a cross-country study of the impact of an euro of private equity financing relative to a euro of industrial R\&D. It focuses on a sample of European countries. Its estimates imply that while private equity investment accounts for $8 \%$ of aggregate private equity plus R\&D industrial spending, PE accounts for as much as $12 \%$ of industrial innovation (Popov \& Roosenboom 2009).

\section{Financing Innovation: Indian Context}

The scope and development of different means of financing innovation in India, which have started to take-off, was narrow and gloomy. It was happened mainly due to the credit constraints resulting from the overemphasis on the socioeconomic issues. It is true that though, at that time, we could get funding for innovative start-ups from commercial banks and government financial institutions, it was provided on the basis of mortgaging sufficient collateral. It was, indeed, very problematic for the new entrepreneurs to start their enterprises, especially for those who wanted to raise financial capital for their fresh ideas of course value creating. Hence, most of them used to be dependent on their own financial resources as well as resources of the family and friends to make real their innovative initiatives (Sahai 2009). However, the recent scenario of financing innovation is completely different form the past. Now we have crowd-funding, angel financing, venture capital, and private equity. Though we have also several direct and indirect governmental schemes for financing of innovation, here I am more concerned about current prospects of private sources of financing or equity financing in India, especially angel investment, venture capital and private equity. 


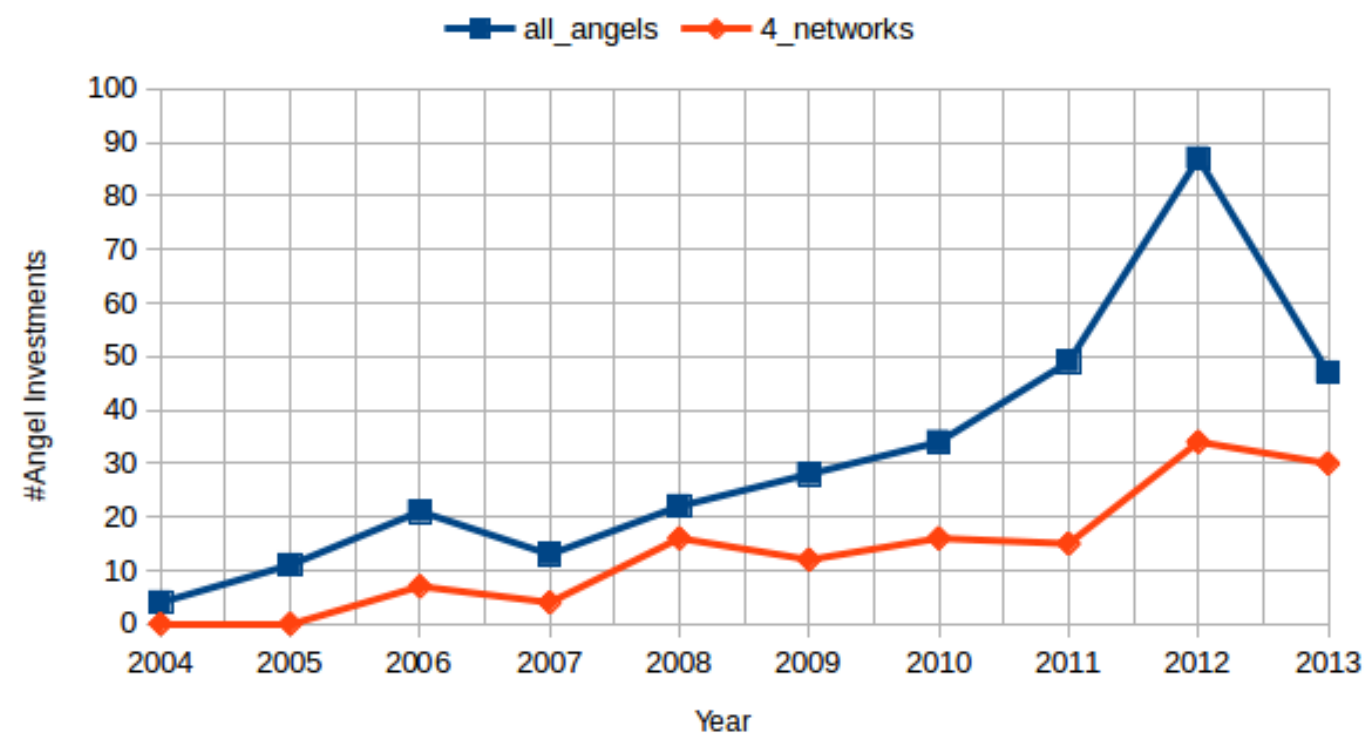

Figure 11: Yearwise Distribution of Angel Investments

\subsection{Angel Investment in India}

Although the angel type of investment has been taking place in India for a long time in the form of private investment in the joint stock companies, it was not known by angel investment. It is a recent development - that has happen with the emergence of modern entrepreneurial finance. The remarkable turning point in the Indian angel investment was the establishment of Indian Angel Network in 2006. Subsequently, the angel investment scenario became more structured through initiation of more such networks in different regions of this country. In fact, over the period the gap between investors and entrepreneurs becomes less and less due to improvement of different internet facilities. But India still has a long way of journey in angel financing for different innovative start-ups. This field is still at the developing stage we can see from the Figure 11 that though yearwise trend of angel investments is rather positive, the number of investments is quite small, suffering from limitation of localisation of financing opportunities. Actually, the distribution of angel investments are concentrated to sophisticated regions like Bangalore, Mumbai, Delhi, Chennai, Pune and Hyderabad and limited trendy companies such as software and online services. However, the overseas angel investments come from investors who, basically, join an Indian syndicate in investing in a company with Indian and overseas operations as well as from foreign wings of Indian Angel Network (Sabarinathan 2014); (Rajan \& Jain 2012).

Nonetheless, the available VI database shows that from the last decade some specific sectors like 


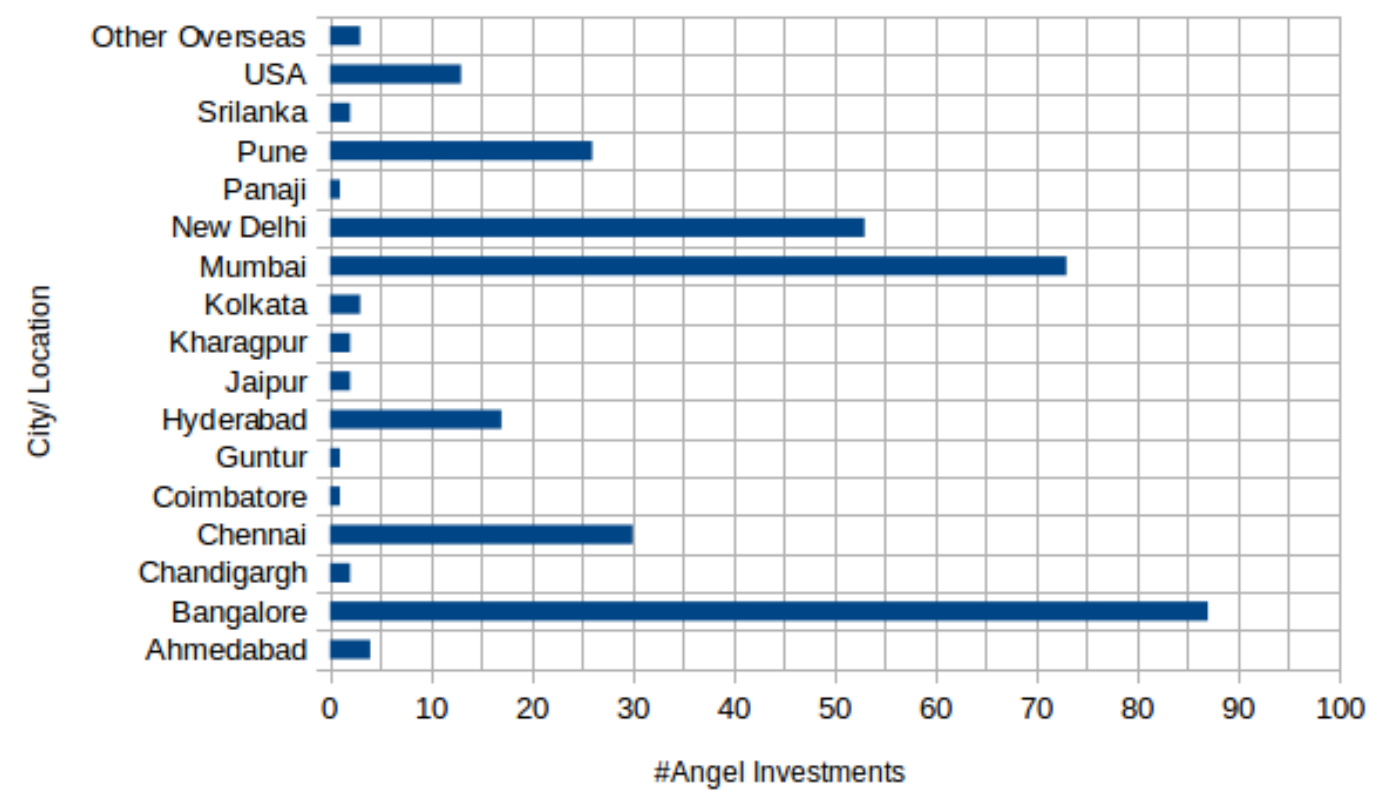

Figure 12: Spatial Distribution of Angel Investments

online services, enterprise software, education, Mobile VAS and e-commerce recently have attracted most of the yearly angel investments towards them. According to G. Sabarinathan, Associate Professor of IIMB, there are several reasons behind this sectoral concentration of angel investments. Basically, investments flow to that sectors which have the flavour of the season or trendy factor, high potential of success in future, hope of getting quick and profitable exits and so on (Sabarinathan 2014). In reality, after angel investment we have to think about financing through venture capital for successful start-up companies. VC investment means formal financing scheme, which requires extreme commitments form the side of entrepreneurs making it more difficult to select a scheme. All angel funded firms are not able to raise VC fund, for example, of the 320 funding transactions reported by the VI database, 59 companies $18 \%$ raised follow-on funding from venture capital investors in the last decade. From the given data in (Sabarinathan 2014) paper, I just run a simple panel data regression model, especially random effects model, to test some financing issues i.e. relative effectiveness of network versus non-network angel investments in deal making as well as raising VC fund, the trend of average time taken to raise VC by companies after angel financing over the concerned period, and sectoral bias in funding etc. All the results of the econometric models are in the Section 6 i.e. Appendix section.

Indeed, after testing I am able to infer that angel networks are much more more than double effective in making deals Models $1 \& 2$ as well as in raising VC more than 4 times than the nonnetworks Model 3. Besides this, it can be tested that the average time taken each year for raising 
VC fund of angel backed start-up firms is falling over time Model 4. Most recent angel financing has taken less time to raise VC for the innovative start-ups Model 5. According to G. Sabarinathan, this could be due to two reasons. First one is: angels gain more heterogeneous experience due to more deals across time to perform such financing management so that they could attract VC financiers. Second reason is: sectoral bias in favour of venture capitalists in angel investment that impress venture capitalists better Model 6. It should be noted that though the angel investment is progressing day by day for financing innovative start-ups in diverse sectors, there is a total absence of the manufacturing sector which might be the engine of growth for this economy.

\subsection{VC investment in India}

India is relatively in a good position for VC financing of innovation. Actually, India after US, Europe and China is, fourth in the global VC ranking, experiencing a $13 \%$ increase in dollars invested with a slight fall $2 \%$ in the number of rounds compared to 2012. Although the overall trend of VC investment is much positive Figure 13, VC financiers continue to be cautious about the early stage, and are increasingly confident in making late-stage financing in innovative companies as they scale Figure 14. Since later-stage has dominated VC financing, angel and incubators as well as accelerators are filling the funding gap in the early-stage. From the table of VC statistics Figure 15, we can note that the exit environment becomes more challenging Model 7. The reasons are recent in 2013 low level of IPO exits, and decline of M\&A activity from 16 deals to 13 deals (Pearce 2014). However, it is true that now-a-days M\&A becomes more or less preferred exit strategy for innovative start-ups.

In reality, if we don't consider the socio-economic perspective, then we, indeed, would commit some mistakes to assess the scenario of VC financing for supporting the new ideas as well as for angels also. It is true that besides screening, monitoring, and due diligence, which are firm level assessments, we need some assessments which are at the economy or the society level. For this reason, it would be rational to think about some measures which benchmark the business confidence or attractiveness of our Indian economy to receive institutional VC funding for innovative start-ups. In this context, we can think about "The Venture Capital and Private Equity Country Attractiveness Index", which is providing analytical pictures about VC/PE investments to not only business or financial community, but also to the politicians for managing/controlling the supply of risk capital in order to a fertile economic basis for innovative or entrepreneurial for future growth and development in their countries. Emerging nations, like India, can attract VC financing by high economic growth potentials. But growth potentials are not the sole factor that make the Indian economy more attractive for VC investments. Actually, for existence of enriched environment for venture capitalists, we have to fulfill some socio-economic and institutional prerequisites. Side by side, we need to recognise a good timing for attracting investors, which can be depicted through that referred multidimensional index (Groh, Liechtenstein \& Lieser 2014). 
Actual and fitted VC_investment

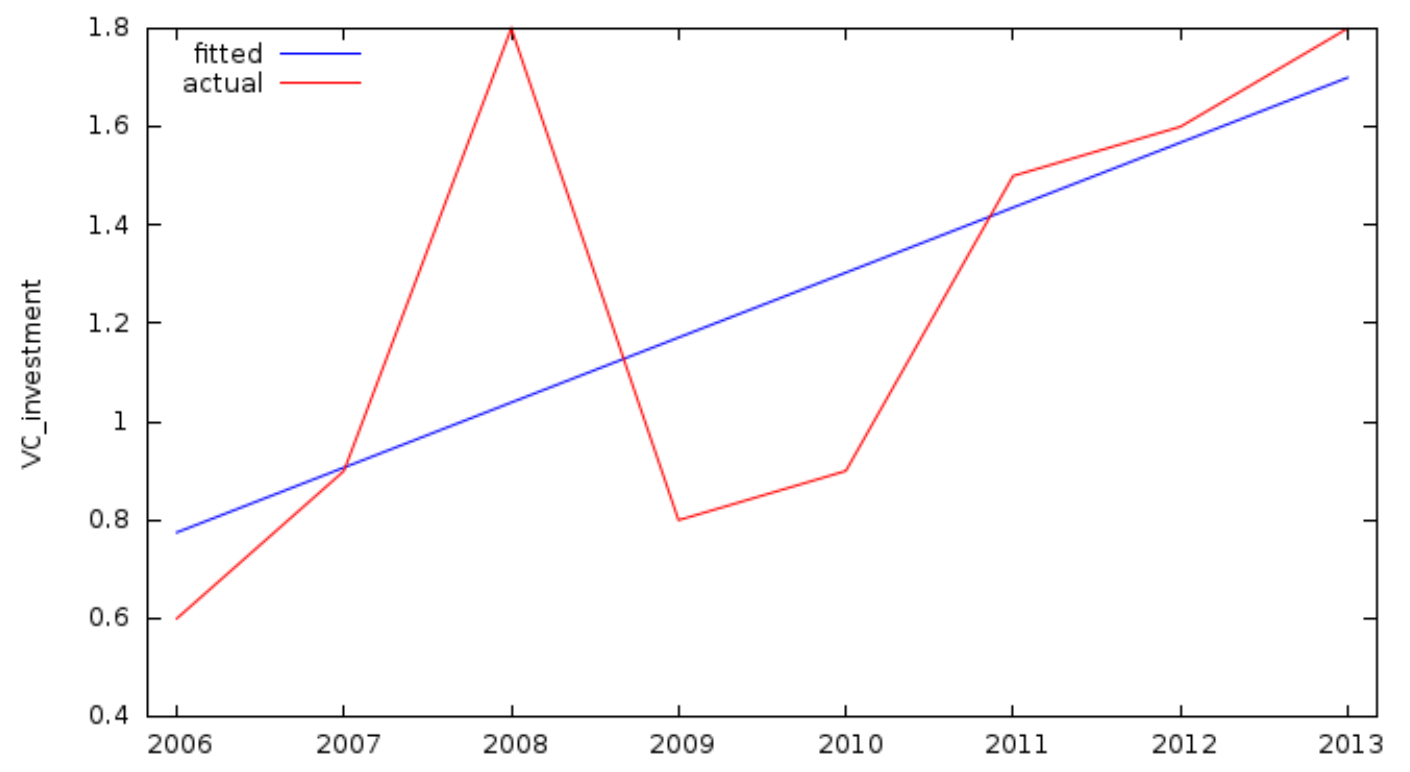

Figure 13: Indian Annual VC Investment 2006-13 US\$b

From the Index's website I get some fundamentals:

Investors in Venture Capital and Private Equity funds have a key objective: to get access to transactions with satisfying risk and return ratios. They look globally to achieve their goals, and often set their sights on emerging regions. To find prime investment opportunities, investors generally look several years down the road and focus on specific factors like: economic activity GDP, inflation, unemployment rate; size and liquidity of capital markets; taxation; investor protection and corporate governance; the human and social environment including human capital, labor market policies and crime; and entrepreneurial culture and opportunities including innovation capacity, the ease of doing business and the development of high-tech industries. The idea of the Venture Capital and Private Equity Country Attractiveness Index is to take into account all of these factors across different nations and to determine the relative positioning of particular economies and regions as they stand in relation with respect to their attractiveness for investment in Venture Capital and Private Equity assets (Groh, Liechtenstein, Lieser \& Biesinger 2014).

In short, this multidimensional index is composed of six items and then each item is also composed of some sub-items. For India Figure 16 we have the following Key Driver Performance in 


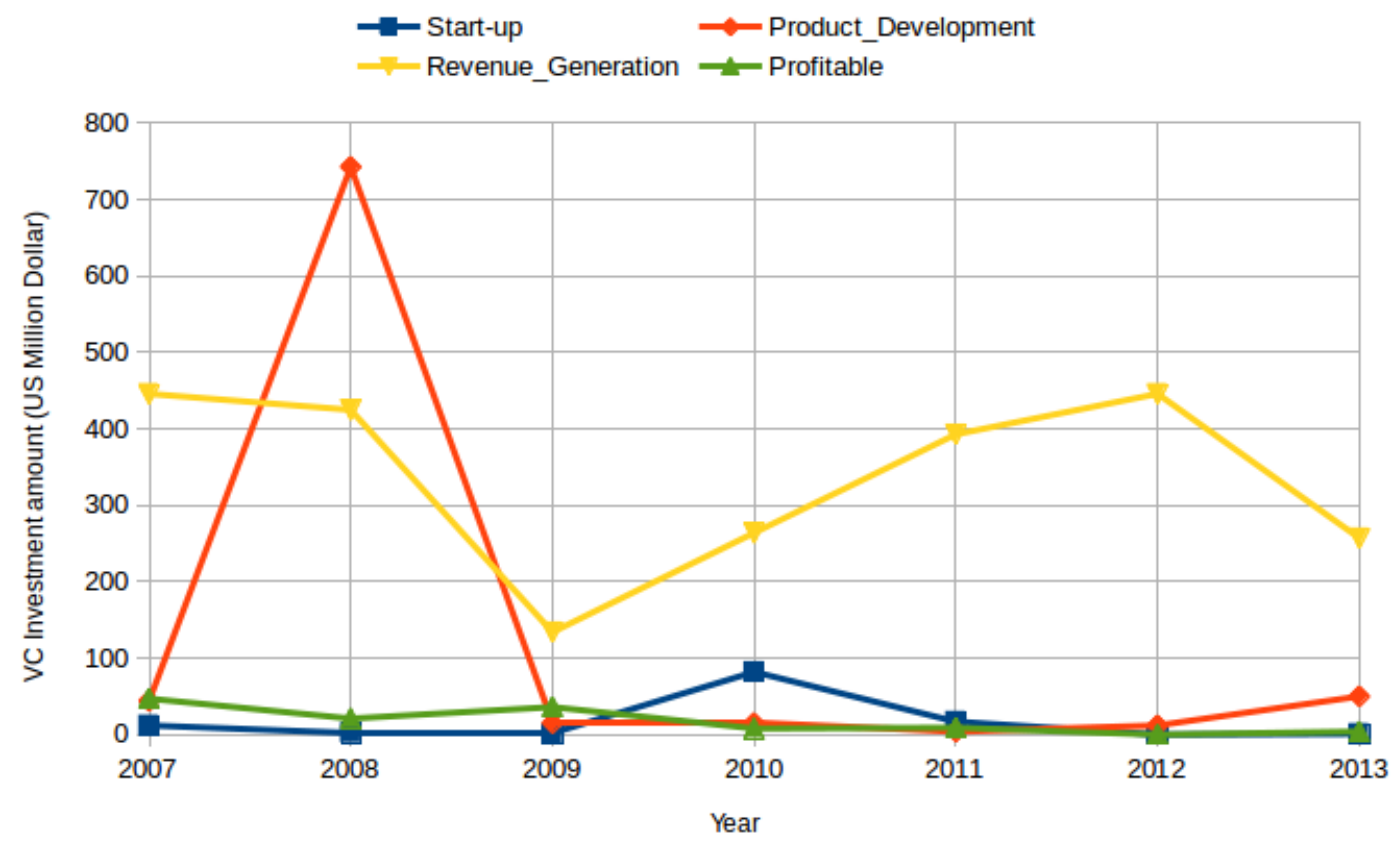

Figure 14: VC financing in different stages of development

\begin{tabular}{|l|c|c|c|c|}
\hline & 2010 & 2011 & 2012 & 2013 \\
\hline Invested capital (US\$b) & 0.9 & 1.5 & 1.6 & 1.8 \\
\hline Invested rounds & 116 & 180 & 227 & 222 \\
\hline Median round size (US\$m) & 7.25 & 5.15 & 3.97 & 4.00 \\
\hline Number of VC-backed IPOS & 6 & 2 & 2 & 1 \\
\hline Dollars raised (US\$m) & 532.5 & 46.4 & 19.5 & 10.9 \\
\hline Median time to exit (years) & 4.3 & $\mathrm{~N} / \mathrm{S}$ & $\mathrm{N} / \mathrm{S}$ & $\mathrm{N} / \mathrm{S}$ \\
\hline Number of VC-backed M\&AS & 16 & 6 & 16 & 13 \\
\hline Median M\&A valuations (US\$m) & 27.0 & $\mathrm{~N} / \mathrm{S}$ & 18.4 & 46.5 \\
\hline Median time to M\&A (years) & 3.5 & 4.1 & 4.0 & 2.6 \\
\hline
\end{tabular}

Source: Dow Jones VentureSource, 2014

Figure 15: VC Summary Statistics of India 
2014. However, Despite its multi-dimensionality, we can doubt that whether this index truly influential in the real world of VC investment or not. In the test of its strength in the real world, I find that the score of this index across time is highly correlated significant with the flow of VC investments Model 9. In another way, I have also found the score elasticity of VC financing, and in this case I get significant high elasticity. The results are in appendix section B. Now, if we analyse the radar chart, we can identify some strengths and weaknesses of our Indian economy for attracting VC financing for fresh start-ups. We are excellent in economic activity and to some extent in capital market, but mostly we have to improve ourselves in the remaining four indicators. Especially, our first priority is to focus more on "Taxation" sub-index as our government is very poor in providing entrepreneurial as well as angel \& VC investment tax credit In the budget 2015-16, there are several proposals for encouraging MSME entrepreneurs, for instance, loans to MSME sector being brought under priority sector, creation of small finance banks to supply credit to MSMEs etc., and reducing Administrative burden. Second priority should be to improve "Human and Social Environment" sub-index, which is in lower position due to labor regulations and excessive bribing \& corruption. Subsequently, we have to take care about "Investor Protection and Corporate Governance" sub-index including security of property rights and quality of legal enforcement. And lastly we have the option to revamp the existing entrepreneurial opportunities through reducing burdens of starting and running a business, maintaining simplicity of closing a business, and incentivising innovation throughout the economy. Therefore, government has to be more active and effective to clear different obstructions on the way of financing fresh and innovative ideas or activities for achieving multi-dimensional growth in the future.

However, in this context if we analyse a brief scenario of private equity in India, then we will see that the Indian PE financing is much more improved than the other two types of financing. In recent past, India witnessed an annual increase in PE/VC deal value by $16 \%$, from $\$ 10.2 \mathrm{~b} 2012$ to $\$ 11.8$ b in 2013. Whereas, deal volume grew by about $26 \%$ from 551 deals in 2012 to 696 deals in 2013 Figure 17. In fact, the overall volume of deals in India increased across sectors. The overall growth of $26 \%$ was predominantly fuelled by the IT and ITES information technology enabled services, health-care and BFSI banking, financial services and insurance sectors. In case of exit, the total number of exits shot up significantly, by $43 \%$ in 2013, but the overall value of exits remained flat at 2012 levels of $\$ 6.8$ billion. Only two sectors-IT and ITES, and BFSI-have shown good returns on the invested PE capital (Sheth et al. 2014). Therefore, we can conclude that those sectors are more likely to contribute product market innovation within the economy. Basically, the same type of sectoral bias can be noticed for angel and VC financing. In practice, it is true that before investment capitalists, generally, do some analysis at sector level as well as at economy level. At that time, the corresponding factors of the society which may be latent might present some sectors relatively more confident from business point of view. Thus, if some sectors become less confident or weak due to some internal and/or external causes in terms of providing returns after exit, then those sectors are always be neglected by private sector. So, still we have some frictions in financing innovation which could be removed only through governmental financing in nationwide innovation and R\&D for a fertile future. 
- United States $=100$ points -

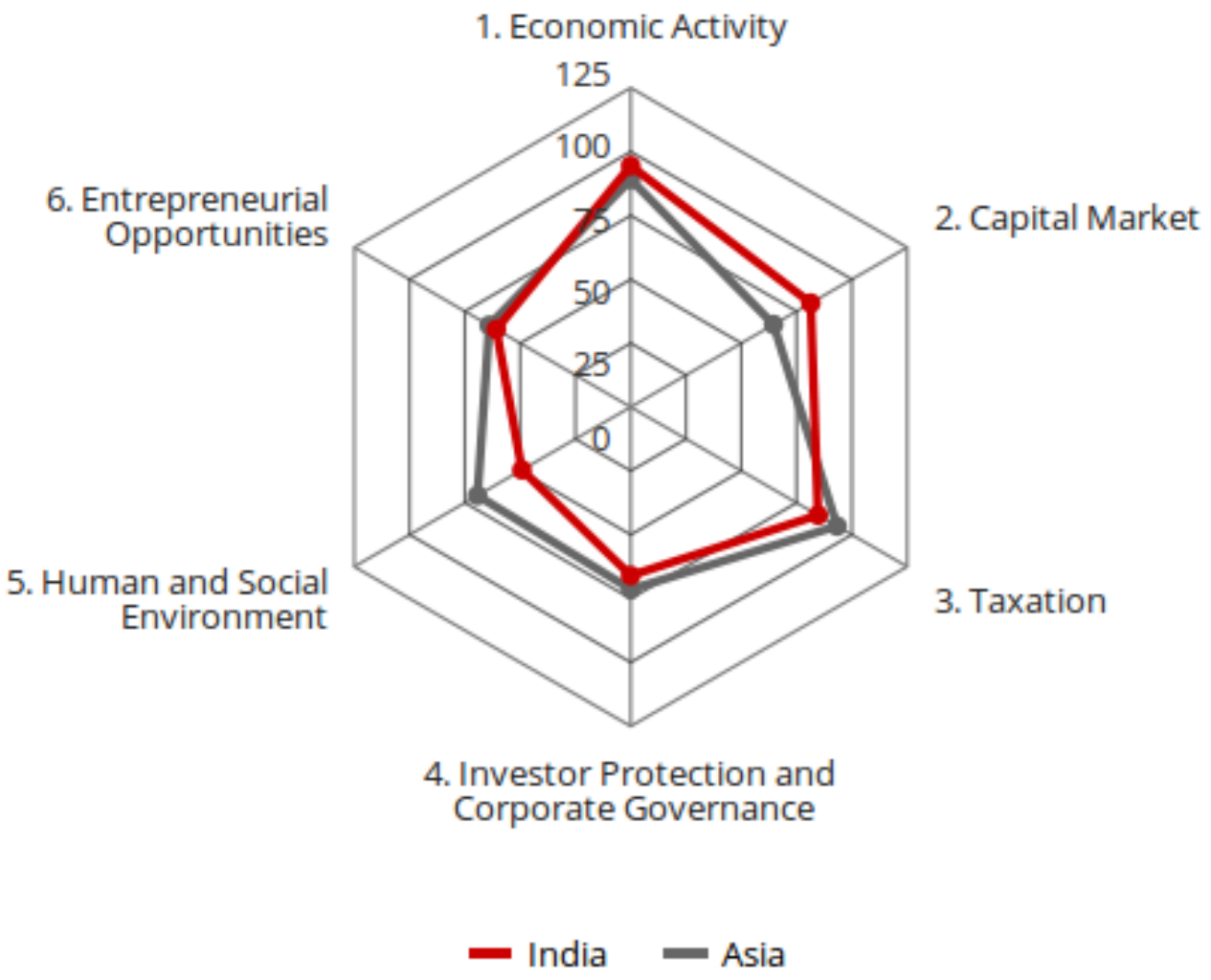

Figure 16: Key Driver Performance in Radar Chart 
Annual PE/VC investment in India

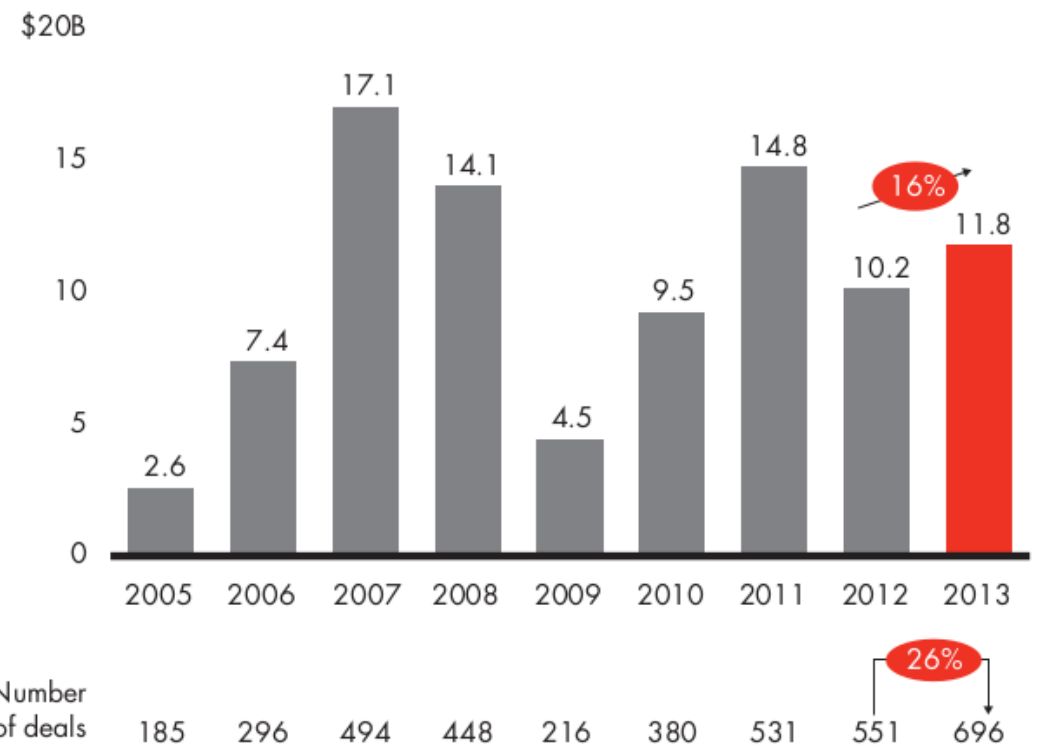

Figure 17: Trend of Indian PE and VC Source: Bain PE deals database

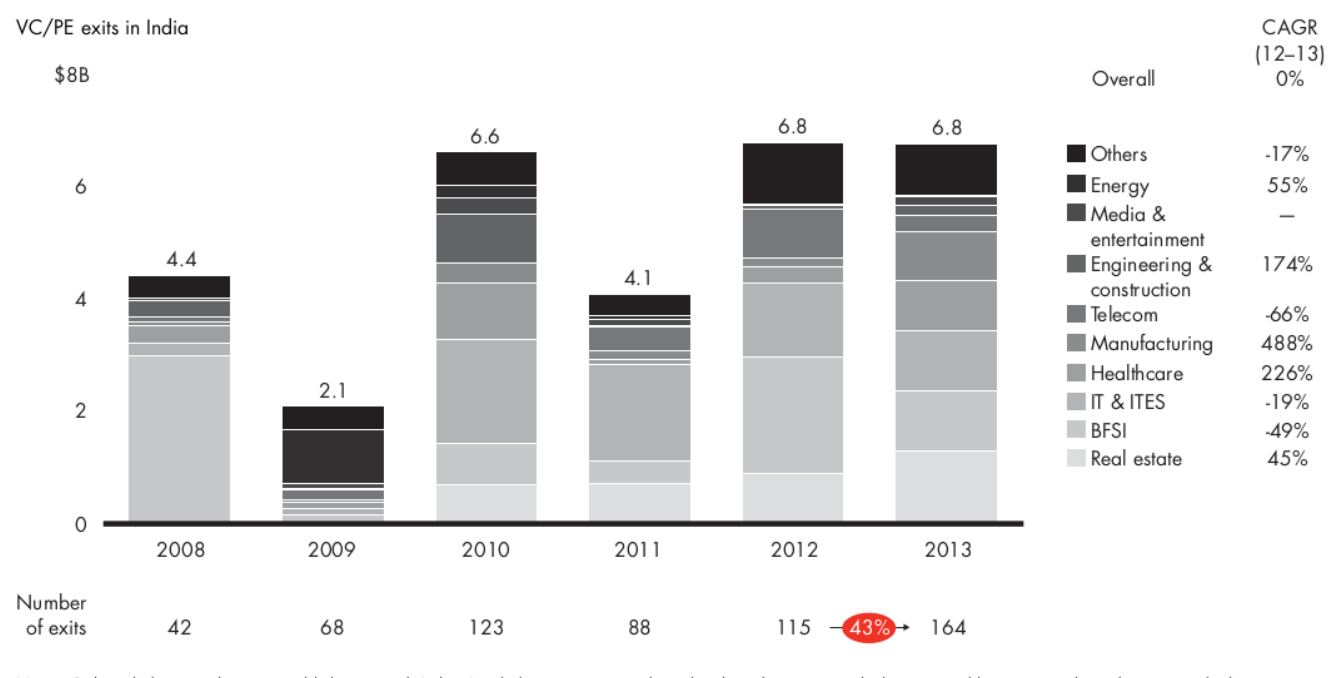

Notes: Only includes exits that were publicly reported; 'others' includes consumer products, hotels and resorts, retail, shipping and logistics, textiles, education and other services. Source: Bain PE exits database

Figure 18: The number of exits increased by more than $40 \%$, but the total exit value remained flat from 2012 to 2013 


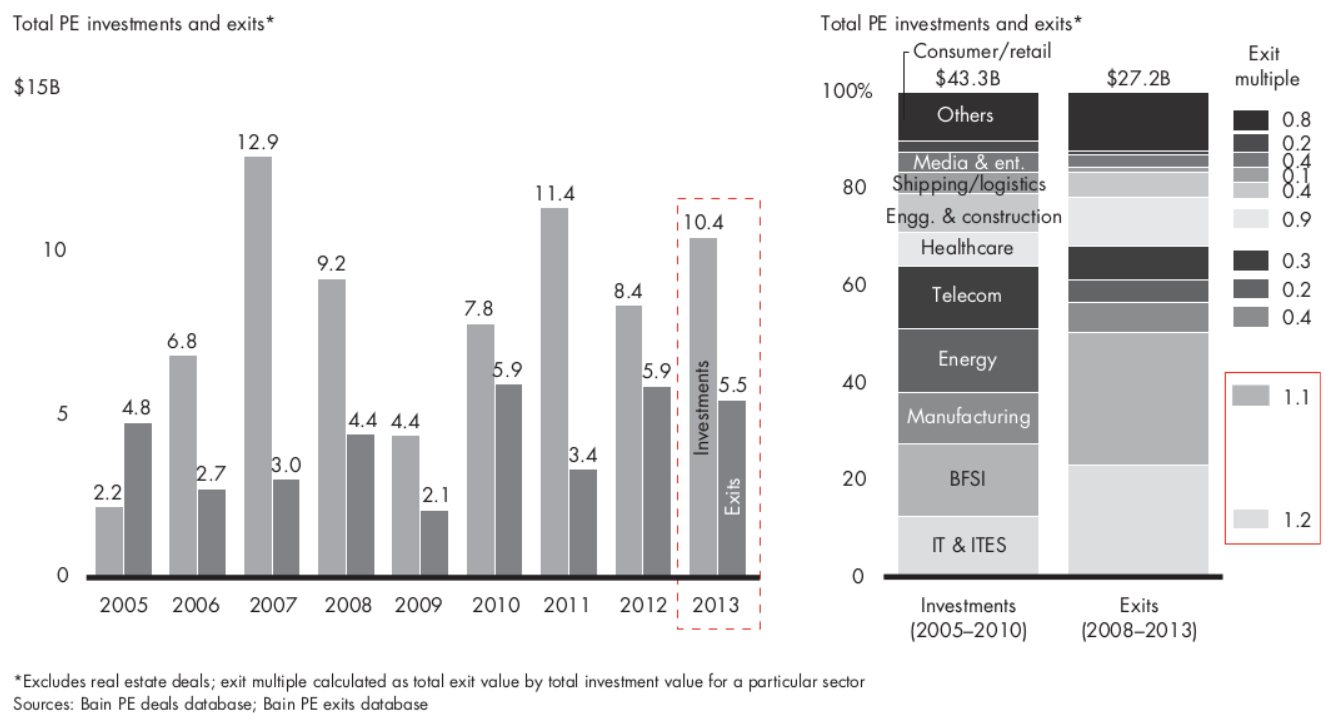

Figure 19: IT/ITES and BFSI have outperformed in terms of returns 


\section{A Way Ahead: Some Implications}

I think that I am, to some extent, failed to show the the effectiveness of angel and VC financing for innovation in India. Actually, when we say something about innovation, it is nothing but some fresh ideas which could create value. And to support that fresh ideas we require some funds. These can be provided through public or private source. In this article, I am more concerned about private sources. But there is a massive role of the government to support those startups through creating a enthusiastic environment for entrepreneurs and/or supporting directly by various means for innovation. Though we can't doubt the government's role in supporting innovation, we would, perhaps, be skeptical about roles of private sources. Generally, to measure the effectiveness of private sources in nurturing product market innovation, especially the roles of angels and venture capitalists, we can use the successful exits as well as sustainable business life after excellent exits. Here, it is implicitly assumed that those angels and venture capitalists would provide support to innovative firms only. In fact, the notion of innovation is broad and multidimensional, and to sustain something in a competitive market you have to be enough innovative to get power to produce value. In this context, we can think about the "Global Innovation Index" poor condition for India; see Model 10, which relies on two sub-indices, the Innovation Input SubIndex and the Innovation Output Sub-Index, each built around key pillars. On one hand, there are five input pillars comprising elements of the national economy that enable innovative activities: 1 Institutions, 2 Human capital and research, 3 Infrastructure, 4 Market sophistication, and 5 Business sophistication. And in another hand, there are two output pillars which reveal actual evidence of innovation outputs: 6 Knowledge and technology outputs and 7 Creative outputs. Each pillar is divided into sub-pillars and each sub-pillar is composed of individual indicators 81 in total. Sub-pillar scores are calculated as the weighted average of individual indicators; pillar scores are calculated as the weighted average of sub-pillar scores (Index 2014).

Now if we talk about the significance of the different private funding in fostering innovation without considering those above components i.e. ceteris paribus condition, but not the principle of general equilibrium, we would commit some mistakes. Indeed, many of the pillars could be controlled through the good government with less narrow politics. Besides this, there are several VC financing different development finance institutions in India which are promoted by central government as well as state governments. I have just skipped them, but they are very much effective for nationwide to grass-root level innovative activities.

Nevertheless, corporate venture capital CVC companies are also important for nurturing innovative start-ups. Corporate venture capital is the least understood category of venture capital. The concept has been around in the U.S. and other developed countries for a long time. Quite a few of the Fortune 100 companies - Intel, Cisco, Unilever, BP - have a separate venture capital entity for such investments. In India, corporate venture capital is a relatively recent phenomenon. Local companies such as Reliance, Airtel and Future Group have started their own investment 


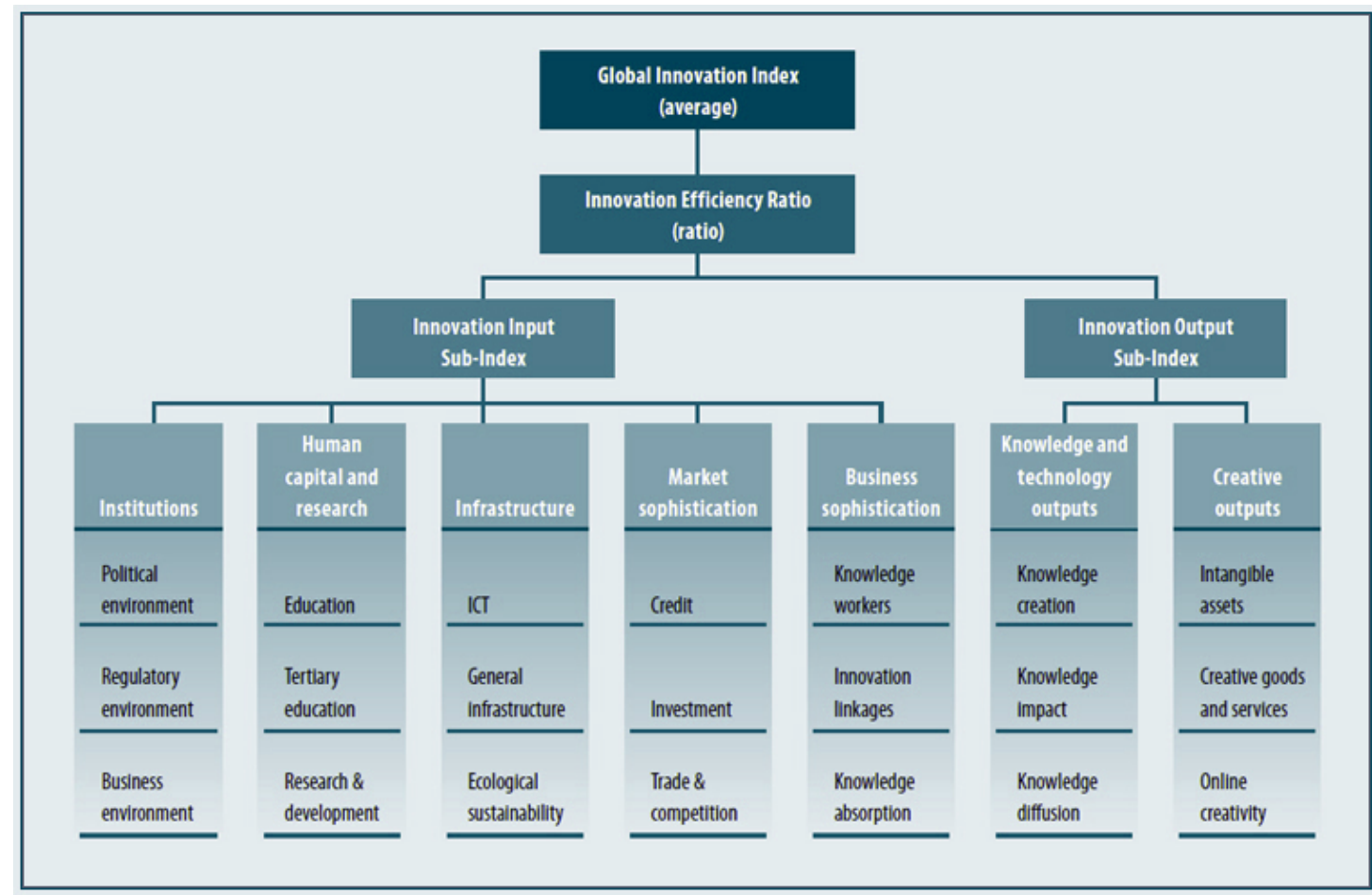

Figure 20: Global Innovation Index 2014 Conceptual Framework

entities. Hence we could say that despite of the trendy means of financing innovation with lump sum exit returns, the ultimate significance of those means should be justified on the basis of that multi-dimensional index of innovation.

\section{Appendix}

\subsection{Results of Panel Data Regression}

Model 1: Random-effects GLS, using 288 observations

Using Nerlove's transformation

Included 24 cross-sectional units

Time-series length $=12$

Dependent variable: AngelInvestments 


\begin{tabular}{lccrl} 
& Coefficient & Std. Error & \multicolumn{1}{c}{$t$-ratio } & $\mathrm{p}$-value \\
const & -387.165 & 63.9970 & -6.0497 & 0.0000 \\
Time & 0.192852 & 0.0318860 & 6.0482 & 0.0000 \\
Network & 0.269197 & 0.0629040 & 4.2795 & 0.0000
\end{tabular}

$\begin{array}{lrll}\text { Mean dependent var } & 1.111111 & \text { S.D. dependent var } & 2.965801 \\ \text { Sum squared resid } & 1568.119 & \text { S.E. of regression } & 2.341566 \\ \text { Log-likelihood } & -652.6870 & \text { Akaike criterion } & 1311.374 \\ \text { Schwarz criterion } & 1322.363 & \text { Hannan-Quinn } & 1315.778\end{array}$

$$
\begin{gathered}
\hat{\sigma}_{\varepsilon}^{2}=5.23754 \\
\hat{\sigma}_{u}^{2}=0.226159 \\
\theta=0.642379
\end{gathered}
$$

Breusch-Pagan test -

Null hypothesis: Variance of the unit-specific error $=0$

Asymptotic test statistic: $\chi^{2} 1=3.86127$

with $\mathrm{p}$-value $=0.0494128$

Hausman test -

Null hypothesis: GLS estimates are consistent

Asymptotic test statistic: $\chi^{2} 1=1.08713 \mathrm{e}-12$

with $\mathrm{p}$-value $=0.999999$

Model 2: Random-effects GLS, using 288 observations

Using Nerlove's transformation

Included 24 cross-sectional units

Time-series length $=12$

Dependent variable: AngelInvestments

\begin{tabular}{lccrl} 
& Coefficient & Std. Error & \multicolumn{1}{c}{$t$-ratio } & $\mathrm{p}$-value \\
const & -386.955 & 63.8692 & -6.0585 & 0.0000 \\
Time & 0.192852 & 0.0318225 & 6.0602 & 0.0000 \\
NonNetwork & 0.115173 & 0.0260638 & 4.4189 & 0.0000
\end{tabular}

Mean dependent var

Sum squared resid

Log-likelihood

Schwarz criterion

$\begin{array}{rlr}1.111111 & \text { S.D. dependent var } & 2.965801 \\ 1520.919 & \text { S.E. of regression } & 2.306057 \\ -648.2860 & \text { Akaike criterion } & 1302.572 \\ 1313.561 & \text { Hannan-Quinn } & 1306.976\end{array}$




$$
\begin{gathered}
\hat{\sigma}_{\varepsilon}^{2}=5.23754 \\
\hat{\sigma}_{u}^{2}=0.0473715 \\
\theta=0.642379
\end{gathered}
$$

Breusch-Pagan test -

Null hypothesis: Variance of the unit-specific error $=0$

Asymptotic test statistic: $\chi^{2} 1=10.6349$

with $\mathrm{p}$-value $=0.00110971$

Hausman test -

Null hypothesis: GLS estimates are consistent

Asymptotic test statistic: $\chi^{2} 1=1.27898 \mathrm{e}-12$

with $\mathrm{p}$-value $=0.999999$

\subsection{Results of Ordinary Regression}

Model 3: OLS, using observations 1-24

Dependent variable: VCFunding

$\begin{array}{lclrl} & \text { Coefficient } & \text { Std. Error } & t \text {-ratio } & \mathrm{p} \text {-value } \\ \text { const } & -1.43658 & 0.627041 & -2.2910 & 0.0330 \\ \text { Network } & 0.487945 & 0.123217 & 3.9600 & 0.0008 \\ \text { NonNetwork } & 0.116521 & 0.0511903 & 2.2762 & 0.0340 \\ \text { Index } & 0.0523530 & 0.0411425 & 1.2725 & 0.2178\end{array}$

$\begin{array}{lrll}\text { Mean dependent var } & 2.458333 & \text { S.D. dependent var } & 4.863164 \\ \text { Sum squared resid } & 38.79213 & \text { S.E. of regression } & 1.392698 \\ R^{2} & 0.928685 & \text { Adjusted } R^{2} & 0.917988 \\ F 3,20 & 86.81593 & \text { P-value } F & 1.22 \mathrm{e}-11 \\ \text { Log-likelihood } & -39.81649 & \text { Akaike criterion } & 87.63297 \\ \text { Schwarz criterion } & 92.34519 & \text { Hannan-Quinn } & 88.88313\end{array}$

Model 4: OLS, using observations 1-11

Dependent variable: Ave_Days_Taken

$\begin{array}{lccrl} & \text { Coefficient } & \text { Std. Error } & t \text {-ratio } & p \text {-value } \\ \text { const } & 341273 . & 66228.5 & 5.1530 & 0.0006 \\ \text { Time } & -169.579 & 32.9868 & -5.1408 & 0.0006\end{array}$




$\begin{array}{lrll}\text { Mean dependent var } & 805.1818 & \text { S.D. dependent var } & 755.8050 \\ \text { Sum squared resid } & 1451165 & \text { S.E. of regression } & 401.5477 \\ R^{2} & 0.745963 & \text { Adjusted } R^{2} & 0.717736 \\ F 1,9 & 26.42788 & \text { P-value } F & 0.000611 \\ \text { Log-likelihood } & -80.45323 & \text { Akaike criterion } & 164.9065 \\ \text { Schwarz criterion } & 165.7022 & \text { Hannan-Quinn } & 164.4048\end{array}$

Model 5: OLS, using observations 1-11

Dependent variable: Ave_Days_Taken

$\begin{array}{llcrl} & \text { Coefficient } & \text { Std. Error } & t \text {-ratio } & \mathrm{p} \text {-value } \\ \text { const } & 1305.20 & 314.599 & 4.1488 & 0.0025 \\ \text { Angeldeals } & -17.2420 & 8.41921 & -2.0479 & 0.0709\end{array}$

$\begin{array}{lrll}\text { Mean dependent var } & 805.1818 & \text { S.D. dependent var } & 755.8050 \\ \text { Sum squared resid } & 3896590 & \text { S.E. of regression } & 657.9927 \\ R^{2} & 0.317873 & \text { Adjusted } R^{2} & 0.242081 \\ F 1,9 & 4.194025 & \text { P-value } F & 0.070850 \\ \text { Log-likelihood } & -85.88577 & \text { Akaike criterion } & 175.7715 \\ \text { Schwarz criterion } & 176.5673 & \text { Hannan-Quinn } & 175.2699\end{array}$

Model 6: OLS, using observations 1-11

Dependent variable: VCFunded

$\begin{array}{lccrl} & \text { Coefficient } & \text { Std. Error } & t \text {-ratio } & \mathrm{p} \text {-value } \\ \text { const } & 906.966 & 937.474 & 0.9675 & 0.3616 \\ \text { Angeldeals } & 0.189861 & 0.0728633 & 2.6057 & 0.0313 \\ \text { Time } & -0.451809 & 0.467800 & -0.9658 & 0.3624\end{array}$

$\begin{array}{lrll}\text { Mean dependent var } & 5.363636 & \text { S.D. dependent var } & 4.455844 \\ \text { Sum squared resid } & 82.79689 & \text { S.E. of regression } & 3.217081 \\ R^{2} & 0.582983 & \text { Adjusted } R^{2} & 0.478728 \\ F 2,8 & 5.591928 & \text { P-value } F & 0.030242 \\ \text { Log-likelihood } & -26.71005 & \text { Akaike criterion } & 59.42010 \\ \text { Schwarz criterion } & 60.61378 & \text { Hannan-Quinn } & 58.66764\end{array}$

Model 7: OLS, using observations 1-4

Dependent variable: IPOs 


\begin{tabular}{lclll} 
& Coefficient & Std. Error & $t$-ratio & p-value \\
\multicolumn{1}{c}{ const } & 10.9667 & 0.859263 & 12.7629 & 0.0061 \\
\multicolumn{1}{c}{ Investment } & -5.66667 & 0.577350 & -9.8150 & 0.0102 \\
& & & & \\
& & & \\
Mean dependent var & 2.750000 & S.D. dependent var & 2.217356 \\
Sum squared resid & 0.300000 & S.E. of regression & 0.387298 \\
$R^{2}$ & 0.979661 & Adjusted $R^{2}$ & 0.969492 \\
$F 1,2$ & 96.33333 & P-value $F$ & 0.010222 \\
Log-likelihood & -0.495220 & Akaike criterion & 4.990440 \\
Schwarz criterion & 3.763028 & Hannan-Quinn & 2.296977
\end{tabular}

Model 8: OLS, using observations 1-4

Dependent variable: IPOs

$\begin{array}{lllrl} & \text { Coefficient } & \text { Std. Error } & t \text {-ratio } & \text { p-value } \\ \text { const } & 10.2056 & 2.19022 & 4.6597 & 0.0431 \\ \text { Rounds } & -0.0400303 & 0.0114379 & -3.4998 & 0.0728\end{array}$

$\begin{array}{lrll}\text { Mean dependent var } & 2.750000 & \text { S.D. dependent var } & 2.217356 \\ \text { Sum squared resid } & 2.070393 & \text { S.E. of regression } & 1.017446 \\ R^{2} & 0.859634 & \text { Adjusted } R^{2} & 0.789452 \\ F 1,2 & 12.24850 & \text { P-value } F & 0.072835 \\ \text { Log-likelihood } & -4.358642 & \text { Akaike criterion } & 12.71728 \\ \text { Schwarz criterion } & 11.48987 & \text { Hannan-Quinn } & 10.02382\end{array}$

Testing Strength of the The Venture Capital \& Private Equity Country Attractiveness Index. The results are:

Correlation coefficients, using the observations 1-4

$5 \%$ critical value two-tailed $=0.9500$ for $\mathrm{n}=4$

$\begin{array}{rrl}\text { VCPE_Score } & \text { VC_Investment } & \\ 1.0000 & 0.9951 & \text { VCPE_Score } \\ & 1.0000 & \text { VC_Investment }\end{array}$

Model 9: OLS, using observations 1-4

Dependent variable: ln_VC_Investment 


\begin{tabular}{lclrl} 
& Coefficient & Std. Error & $t$-ratio & p-value \\
\multicolumn{1}{c}{ const } & -4.76116 & 0.251358 & -18.9418 & 0.0028 \\
\multicolumn{1}{c}{ ln_VCPE_Score } & 1.25401 & 0.0617146 & 20.3196 & 0.0024 \\
& & & \\
Mean dependent var & 0.339474 & S.D. dependent var & 0.306012 \\
Sum squared resid & 0.001354 & S.E. of regression & 0.026022 \\
$R^{2}$ & 0.995179 & Adjusted $R^{2}$ & 0.992769 \\
$F 1,2$ & 412.8854 & P-value $F$ & 0.002413 \\
Log-likelihood & 10.30585 & Akaike criterion & -16.61169 \\
Schwarz criterion & -17.83910 & Hannan-Quinn & -19.30516
\end{tabular}

Model 10: OLS, using observations 1-7

Dependent variable: GII_Score

$\begin{array}{lccrl} & \text { Coefficient } & \text { Std. Error } & t \text {-ratio } & \mathrm{p} \text {-value } \\ \text { const } & 5290.61 & 863.853 & 6.1244 & 0.0017 \\ \text { Time } & -2.61118 & 0.429655 & -6.0774 & 0.0017\end{array}$

$\begin{array}{lrll}\text { Mean dependent var } & 40.64551 & \text { S.D. dependent var } & 7.336231 \\ \text { Sum squared resid } & 38.50302 & \text { S.E. of regression } & 2.774996 \\ R^{2} & 0.880767 & \text { Adjusted } R^{2} & 0.856920 \\ F 1,5 & 36.93460 & \text { P-value } F & 0.001743 \\ \text { Log-likelihood } & -15.89946 & \text { Akaike criterion } & 35.79892 \\ \text { Schwarz criterion } & 35.69074 & \text { Hannan-Quinn } & 34.46184\end{array}$

\section{Bibliography}

Baumol, W. J. (2004), The Free-Market Innovation Machine: Analyzing the Growth Miracle of Capitalism, Princeton University Press.

Brettel, M. (2014), 'Entrepreneurial finance’, RWTH Aachen Entrepreneurship - Youtube.

Chemmanur, T. J. \& Fulghieri, P. (2014), 'Entrepreneurial finance and innovation: An introduction and agenda for future research', The Review of Financial Studies 27(1).

Chemmanur, T. J., Krishnan, K. \& Nandy, D. K. (2011), 'How does venture capital financing improve efficiency in private firms? a look beneath the surface', Review of financial studies p. hhr096. 
Dicks, D. \& Fulghieri, P. (2014), 'Uncertainty and innovation'. It is a Preliminary and incomplete paper (November 19, 2014). It was presented in a conference on Entrepreneurship and Finance (December 4, 2014) at HKUST Jockey Club Institute for Advanced Study.

Dictionary.com (2015), 'Finance'. URL: http://dictionary.reference.com/browse/finance

for Europe, U. N. E. C. (2009), Policy options and instruments for financing innovation: A practical guide to early-stage financing, Technical report, UNITED NATIONS, New York and Geneva.

Frontier Economics Ltd, L. (2014), Rates of return to investment in science and innovation, Technical report, Tech. rep. A Report Prepared for the Department for Business, Innovation and Skills (BIS).

Goldfarb, B., Hoberg, G., Kirsch, D. \& Triantis, A. (2009), 'Does angel participation matter? an analysis of early venture financing', Unpublished working paper.

Groh, A., Liechtenstein, H. \& Lieser, K. (2014), The venture capital and private equity country attractiveness index - 2013 annual, Technical report, IESE Business School, University of Navarra.

Groh, A., Liechtenstein, H., Lieser, K. \& Biesinger, M. (2014), 'The venture capital and private equity country attractiveness index', Accessed December 30.

Hall, B. H. (2002), 'The financing of research and development', Oxford Review of Economic Policy.

Hellman, T. \& Puri, M. (2000), 'The interaction between product market and financing strategy: The role of venture capital', Review of Financial studies 13(4), 959-984.

Index, G. I. (2014), 'The human factor in innovation', INSEAD (The Business School for the World) and the World Intellectual Property Organization (WIPO).[felektronnyj resurs]. Rezhim dostupa: http://www. wipo. int/econ_stat/en/eco-nomics/gii (data obrashhenija: 20.06. 2015).

Jalonen, H. (2012), 'The uncertainty of innovation: A systematic review of the literature', fournal of Management Research 4(1).

Jaruzelski, B., Staack, V. \& Goehle, B. (2014), Global innovation 1000: Proven paths to innovation success, Technical report, pwc and strategy\&.

Kerr, W. R., Lerner, J. \& Schoar, A. (2014), 'The consequences of entrepreneurial finance: Evidence from angel financings', Review of Financial Studies 27(1), 20-55.

Kerr, W. R. \& Nanda, R. (2014), 'Financing innovation', NBER Working Paper No. 20676.

Kumar, N. \& Puranam, P. (2012), India Inside: The Emerging Innovation Challenge to the West, Harvard Business Review Press.

Lerner, J., Sorensen, M. \& Strömberg, P. (2011), 'Private equity and long-run investment: The case of innovation', The fournal of Finance 66(2), 445-477. 
Mazzucato, M. (2013), 'Financing innovation: creative destruction vs. destructive creation', Industrial and Corporate Change 22(4), 851-867.

Pearce, B. (2014), Adapting and evolving: Global venture capital insights and trends 2014, Technical report, Ernst \& Young.

Popov, A. \& Roosenboom, P. (2009), 'Does private equity investment spur innovation? evidence from europe', $E C B$ working paper .

Rajan, T. \& Jain, A. (2012), India venture capital and private equity report 2012, Technical report, Department of Management Studies, Indian Institute of Technology Madras.

Sabarinathan, G. (2014), Understanding angel investing in india-an exploratory study based on publicly available data, in 'WP No. 448', Indian Institute of Management Bangalore.

Sahai, P. (2009), Smooth Ride to Venture Capital, Vision Books.

Schumpeter, J. (1934), The Theory of Economic Development, Harvard University Press, Boston.

Sherman, A. J. (2012), Raising Capital, third edition edn, AMACOM.

Sheth, A., Singhal, M. \& Taneja, P. (2014), India private equity report 2014, Technical report, Bain \& Company India Pvt. Ltd. and IVCA.

van Tilburg, R. (2009), Finance for innovation, Technical report, Dutch Advisory Council on Science and Technology Policy.

Wikipedia (2015), 'Entrepreneurial finance'. [Online; accessed 14-Feb-2015]. 